\title{
A INOVAÇÃO NO BRASIL: A ANÁLISE DOCUMENTAL DO DECRETO Nº 61.056/1967
}

\author{
INNOVATION IN BRAZIL: \\ THE DOCUMENTAL ANALYSIS OF LEGAL ACT Nº 61.056 / 1967
}

\author{
LA INNOVACIÓN EN BRASIL: \\ EL ANÁLISIS DOCUMENTAL DEL DECRETO № 61.056 / 1967
}

https: / / orcid.org/0000-0002-1972-3589 / http://lattes.cnpq.br/6439935516374065 / elisacoimbra775@yahoo.com.br
Universidade do Estado do Rio de Janeiro (UERJ)
Rio de Janeiro, RJ, Brasil.

Marcos Vinício Chein Feres https://orcid.org/0000-0001-5045-3436 / http://lattes.cnpq.br/0515333775813047 / mvchein@gmail.com Universidade Federal de Juiz de Fora (UFJF) Juiz de Fora, MG, Brasil.

LEONARDO dA SILVA SANT'ANNA https://orcid.org/0000-0002-5192-2844 / http://lattes.cnpq.br/6331238684423252/ santanna44@gmail.com Universidade do Estado do Rio de Janeiro (UERJ)

Rio de Janeiro, RJ, Brasil.

\begin{abstract}
RESUMO
Este artigo analisa a política de fomento público à inovação no momento em que ela começou a ser sistematizada, ou seja, no momento da constituição da Financiadora de Estudos e Projetos (Finep), na década de 1960. O objetivo é o de analisar como tal sistematização foi operacionalizada, reconhecendo as condições de possibilidade e as limitações deste processo. A metodologia adotada neste trabalho é a análise documental do decreto de criação da Finep, tal como elaborada por André Cellard (2008). Nesta linha, procede-se a uma análise prévia do documento, levando em consideração, entre outros elementos, os contextos econômico, político e social, bem como a sua lógica interna. Por fim, a inferência descritiva consiste na explicitação dos elementos que foram relevantes para elaboração do documento legal, de modo a finalmente indicar como as políticas de fomento público à inovação podem ser executadas.
\end{abstract}

Palavras-chave: Decreto n 61.056/1967; Finep; inovação.

\begin{abstract}
This article aims to analyze the public policy of innovation when it has firstly been systematized, that is, at the moment of the constitution of Financiadora de Estudos e Projetos (Finep), in the 60s. The objective is to analyze how this systematization was operationalized, taking into account the conditions of possibility as well as the limitations of this process. The methodology adopted in this research is the documental analysis of the legal Act of constitution of Finep, as elaborated by André Cellard (2008). In this vein, a premilinar analysis of the document is carried out, taking into consideration, among others, the economic, political and social context, as well as its internal logic. Therefore, the descriptive inference consists of the explicitation of the elements which were relevant to the elaboration of the legal document so as to, finally, indicate how public policy of innovation may be executed.
\end{abstract}

Keywords: Legal Act \# 61.056/1967; Finep; innovation. 
A INOVAÇÃO NO BRASIL: A ANÁLISE DOCUMENTAL DO DECRETO Nº 61.056/1967

\section{RESUMEN}

Este artículo analiza la política de fomento público a la innovación en el momento en que ella comenzó a ser sistematizada, o sea, en el momento de la constitución de la Financiadora de Estudios y Proyectos (Finep), en la década de 1960. El objetivo es analizar cómo dicha sistematización fue hecha, reconociendo las condiciones de posibilidad y las limitaciones de este proceso. La metodología adoptada en este trabajo es el análisis documental del decreto de creación de la Finep, tal como fue elaborada por André Cellard (2008). En esta línea, se procede a un análisis previo del documento, teniendo en cuenta, entre otros elementos, los contextos económico, político y social, así como su lógica interna. Por último, la inferencia descriptiva consiste en la explicitación de los elementos que fueron relevantes para la elaboración del documento legal, para finalmente indicar cómo las políticas de fomento público a la innovación pueden ser ejecutadas.

Palabras clave: Decreto n 61.056/1967; Finep; innovación.

\section{SUMÁRIO}

INTRODUÇAO; 1 METODOLOGIA DE PESQUISA; 2 A ANÁLISE PRÉVIA; 2.10 contexto da edição do Decreto $\mathrm{n}^{\circ}$ 61.056/1967; 2.2. 0 autor do Decreto $\mathrm{n}^{\circ} 61.056 / 1967 ; 2.3$. As características e natureza do Decreto $\mathrm{n}^{\circ}$ 61.056/1967; 2.4. A lógica interna do Decreto $n^{\circ}$ 61.056/1967; 3. DISCUSSÃO DOS RESULTADOS; 3.1 Política Econômica e a Criação da Finep; 3.2. A relação entre o tipo empresarial, objeto social e interesse social; 3.3. O papel do investimento estrangeiro no exercício das atribuições da Finep; CONCLUSÃO; REFERÊNCIAS.

\section{INTRODUÇÃO}

O fomento público à inovação atualmente é uma competência estatal, assumida na própria Constituição da República Federativa Brasileira de 1988 (CRFB/1988) ${ }^{1}$, consubstanciando a importância do tema para a sociedade como um todo. À medida que as sociedades se tornam mais complexas, o tema da inovação assume maior relevância e, por conseguinte, transforma-se também em objeto de políticas públicas, sejam econômicas (geração de renda e riqueza por meio da criação de novos serviços ${ }^{2}$, comércio e indústrias), sejam sociais (geração de empregos e melhoria das condições de vida das pessoas) ${ }^{3}$.

\footnotetext{
${ }^{1}$ Desde a promulgação da CRFB/1988, o artigo 218 ocupou-se da regulamentação das políticas de ciência e tecnologia. Posteriormente, em 2015, foi aprovada a Emenda Constitucional $n^{\circ} 85 / 2015$, a qual alterou diversos dispositivos incluindo a expressão "inovação" em uma série de outros artigos, inclusive relativos à competências dos entes federativos.

${ }^{2}$ Um exemplo de desafio atual em inovação pode ser encontrado no trabalho: PARENTONI, Leonardo Netto; VALENTINI, Rômulo Soares; ALVES, Tárik César Oliveira e. Panorama da regulação da inteligência artificial no Brasil: com ênfase no PLS N. 5.051/2019. Revista Eletrônica do Curso de Direito da UFSM, Santa Maria, RS, v. 15, n. 2, e43730, mai./ago. 2020. ISSN 1981-3694. DOI: http://dx.doi.org/10.5902/1981369443730. Disponível em: https://periodicos.ufsm.br/revistadireito/article/view/43730. Acesso em: 24 set. 2020.

${ }^{3}$ Sobre o tema veja: VETTORATO, Jardel Luís. LEI DE INOVAÇÃO TECNOLÓGICA: Os aspectos legais da inovação no Brasil. Revista Eletrônica do Curso de Direito da UFSM, v. 3, n. 3, 2008. Disponível em: https://periodicos.ufsm.br/revistadireito/article/view/7016/4235. Acesso em: 13 de mar. de 2019.
} 
ISSN 1981-3694

(DOI): $10.5902 / 1981369437818$

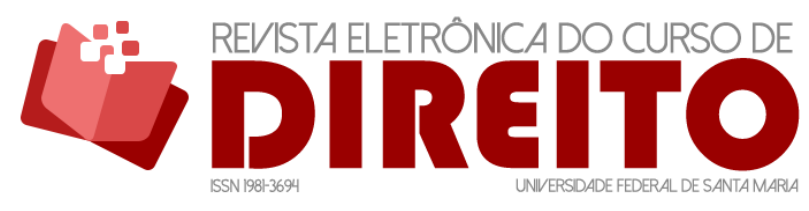

A INOVAÇÃO NO BRASIL: A ANÁLISE DOCUMENTAL DO DECRETO Nº 61.056/1967

ELISA MARA COIMBA MARCOS VINÍCIO CHEIN FERES LEONARDO DA SILVA SANT'ANNA

Neste contexto, estuda-se o processo de sistematização do fomento público à inovação no Brasil, o qual coincide com o momento de criação da Finep (Financiadora de Estudos de Projetos S.A.) na década de 1960, ainda hoje a principal agência de fomento institucional público, voltada diretamente para ciência, tecnologia e inovação ${ }^{4}$. Nesta linha, a pergunta que se formula é: como o fomento à inovação foi sistematizado pela criação da Finep para apoiar as atividades econômicas do país?

Hipoteticamente, afirma-se que a sistematização da política de inovação por meio da criação da Finep esteve associada a um plano de governo internamente coerente. Ao estudar o tema sob esta perspectiva, busca-se subsidiar reflexões futuras a respeito das atuais estruturas institucionais de fomento por vezes sobrepostas e descoordenadas ${ }^{5}$.

Dessa forma, toma-se a criação da Finep como o ponto de partida para a sistematização do incentivo, dado que, por meio dessa estatal, as políticas públicas relacionadas à inovação passaram a ser planejadas no âmbito governamental e executadas, em tese, harmonicamente com ele, deixando que aspectos circunstanciais tivessem menos impactos no direcionamento dos investimentos. Assim, objetiva-se compreender como se empreendeu a sistematização do fomento à inovação, por meio da criação da Finep.

Para tal, utiliza-se como referencial teórico as considerações políticas e econômicas de Luiz Carlos Bresser-Pereira ${ }^{6}$ que auxiliam a contextualização do momento de edição do Decreto $n^{\circ}$ 61.056/1967, juntamente com a metodologia de análise documental proposta por André Cellard ${ }^{7}$, adotada neste trabalho.

\section{METODOLOGIA DE PESQUISA}

Neste trabalho, a abordagem metodológica escolhida é a análise documental do Decreto n 61.056/1967, que regulamenta a criação da Finep, autorizada pelo artigo 191, do Decreto-lei $n^{\circ} 200 / 1967$. De um lado, a análise tem como vantagem colaborar para uma reconstituição direta

\footnotetext{
${ }^{4}$ BRASIL. Tribunal de Contas da União. Relatório de Levantamento. Plenário. TC-002.105/2012-8. Atan ${ }^{\circ}$ 29/2012. Data da sessão: 1/8/2012. Disponível em: https://portal.tcu.gov.br/inicio/. Acesso em: 24set. de 2020.

${ }^{5}$ BRASIL. Tribunal de Contas da União. ACÓRDÃO 1237/2019. Plenário. TC 017.220/2018-1. Ata n 18/2019. Data da sessão: 25/9/2019. Disponível em: https://portal.tcu.gov.br/inicio/. Acesso em: 24 set. de 2020. ${ }^{6}$ BRESSER-PEREIRA, Luiz Carlos. A construção política do Brasil: sociedade, economia e Estado desde a Independência. 3 ed. São Paulo: Editora 34, 2016.

7 CELLARD, André. A análise documental. POUPART, J. et al. A pesquisa qualitativa: enfoques epistemológicos e metodológicos. Petrópolis:Vozes, 2008, p. 295-316.
} 
ISSN 1981-3694

(DOI): $10.5902 / 1981369437818$

A INOVAÇÃO NO BRASIL: A ANÁLISE DOCUMENTAL DO DECRETO Nº 61.056/1967

dos fatos registrados em documentos, especialmente quando a memória viva já não tem mais tais informações. Por outro lado, os documentos podem não reproduzir exatamente a realidade dos fatos, razão pela qual uma postura crítica do pesquisador em relação às circunstâncias em que esses documentos são produzidos tem o potencial de amenizar as desvantagens do método e incrementar a qualidade da pesquisa.

Segundo Cellard $^{8}$, antes de começar a análise documental em si, após a escolha do documento a ser analisado, faz-se necessária uma análise preliminar do documento. Primeiramente, deve-se aceitar o documento tal como ele é, posto que incompleto, impreciso ou parcial, especialmente quando escassos os registros sobre o fato investigado.

Nesta linha, o autor elenca uma série de etapas, ainda dentro da análise preliminar, que ajudam o pesquisador a levantar informações, as quais serão utilizadas para a análise do documento em si, dotando o pesquisador de informações que the permitirão avaliar adequadamente o objeto da investigação. As principais etapas são o levantamento de informações sobre o contexto no qual o documento foi produzido, sobre a identidade da pessoa que elabora o documento, sobre a autenticidade e confiabilidade do texto, sobre a natureza do texto e, finalmente, sobre os conceitos chave e a lógica interna do texto.

Após essa fase inicial, o pesquisador reúne os elementos da análise preliminar, os elementos da problemática e passa a fazer uma interpretação coerente dos fatos, de modo a responder aos questionamentos iniciais. Neste tipo de metodologia, trabalha-se com o método indutivo, embora o pesquisador não elabore um esquema indutivo fechado. .Assim, este esquema pode ser alterado na medida em que novas descobertas são encontradas e consideradas relevantes para a pesquisa ${ }^{9}$. Uma limitação deste tipo de abordagem metodológica diz respeito à possibilidade de se identificarem as funções e atribuições a serem executadas pela Finep sem, contudo, identificar efeitos e resultados decorrentes de sua atuação, de acordo com as atribuições previstas no Decreto $n^{\circ} 61.056 / 1967$. Para tal, uma pesquisa quantitativa/qualitativa em profundidade seria mais apropriada, o que não é o escopo desse trabalho.

\footnotetext{
${ }^{8}$ CELLARD, André. A análise documental. POUPART, J. et al. A pesquisa qualitativa: enfoques epistemológicos e metodológicos. Petrópolis:Vozes, 2008, p. 295-316.

${ }^{9}$ Para mais informações sobre essa metodologia, remete-se à obra Archéologie du savoir, de Michel Focault (1969).
} 


\section{A ANÁLISE PRÉVIA}

\subsection{0 contexto da edição do Decreto $n^{\circ} 61.056 / 1967$}

Nesta etapa, Cellard ${ }^{10}$ entende que deve ser examinado o contexto social global no qual foi produzido o documento, não prescindindo do exame da conjuntura política, econômica, social e cultural.

No caso, ao se analisar o decreto de criação da Finep, Decreto n 61.056/1967, verifica-se que a sua edição ocorreu após a instauração do regime militar (1964), seis meses depois da Constituição da República Federativa do Brasil de 1967 (CRFB/1967) ${ }^{11}$ e três meses após Costa e Silva ter assumido a Presidência da República.

Tais marcos são importantes para contextualizar o momento de criação da Finep. Meses após o término do governo de Castello Branco, caracterizado, nas palavras de Luiz Carlos BresserPereira ${ }^{12}$, por um Pacto Autoritário Modernizante, definido como um pacto desenvolvimentista que excluía trabalhadores e as esquerdas. E pouco antes do auge de popularidade da ditadura militar, conhecido como "milagre econômico", período concomitante à escalada do cerceamento de direitos individuais, apoiada no que ficou conhecido como Doutrina da Segurança Nacional ${ }^{13}$.

Neste contexto, embora o Decreto $n^{\circ}$ 61.056/1967 tenha sido editado no início do governo do Costa e Silva, verifica-se que o governo do Castello Branco influenciou de maneira determinante para a sua edição, especialmente considerando que a autorização para a criação da Finep deu-se por meio do Decreto-lei $n^{\circ} 200 / 1967$, ainda no governo deste último.

No governo de Castello Branco, a preocupação foi com um ajuste macroeconômico às custas de um crescimento menos intenso do que ocorreria posteriormente, o "milagre econômico". Para Bresser-Pereira $^{14}$, o governo Castello Branco foi um governo liberal porque acreditava nas forças

\footnotetext{
10 CELLARD, André. A análise documental. POUPART, J. et al. A pesquisa qualitativa: enfoques epistemológicos e metodológicos. Petrópolis: Vozes, 2008, p. 295-316.

${ }^{11}$ Apesar de se autodenominar de promulgada, a CRFB/1967 foi proclamada sob a pressão do governo militar, o qual conferiu poder constituinte ao Congresso Nacional, por meio do Ato Intitucional $n^{\circ} 4 / 1966$, para que assim o fizesse.

12 BRESSER-PEREIRA, Luiz Carlos. A construção política do Brasil: sociedade, economia e Estado desde a Independência. 3 ed. São Paulo: Editora 34, 2016, p. 191.

${ }^{13}$ Trata-se de uma doutrina formulada pela Escola Superior de Guerra constituída de elementos ideológicos, diretrizes para infiltração, coleta de informações e planejamento político-econômico de programas governamentais (ALVES, Maria Helena Moreira. Estado e oposição no Brasil (1964-1984). Bauru: Edusc, 2005, p. 42)

${ }^{14}$ BRESSER-PEREIRA, Luiz Carlos. A construção política do Brasil: sociedade, economia e Estado desde a Independência. 3 ed. São Paulo: Editora 34, 2016, p. 192-193.
} 
ISSN 1981-3694

(DOI): $10.5902 / 1981369437818$

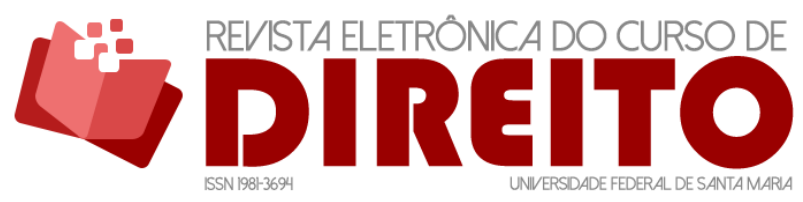

A INOVAÇÃO NO BRASIL: A ANÁLISE DOCUMENTAL DO DECRETO Nº 61.056/1967

ELISA MARA COIMBA MARCOS VINÍCIO CHEIN FERES LEONARDO DA SILVA SANT'ANNA

do mercado e buscava um equilíbrio monetário. Bresser-Pereira ${ }^{15}$ confirma essa hipótese com o dado de que, nos três anos de governo de Castello Branco, as finanças foram organizadas e estruturadas, por meio, entre outras, das reformas tributária, bancária, criação da correção monetária dos ativos financeiros e criação do Banco Central, e, por conseguinte, a inflação que chegara aos $94 \%$ em 1962, baixou para 25\% em 1967, de modo que a recessão econômica nos anos 65-66 decorreu da política de estabilização.

Por sua vez, o Pacto Autoritário Modernizante foi alvo de intensas críticas formuladas pela esquerda, o que deu origem a teorias que ficaram conhecidas como teorias da dependência ${ }^{16}$, que estudam o desenvolvimentismo sob a perspectiva da coalizão de classes, na tentativa de explicar as derrotas políticas que enfrentaram em relação ao golpe militar no Brasil e nos demais Estados. Segundo Bresser-Pereira ${ }^{17}$, a tese central dessas interpretações diz respeito à identificação de que não existe uma burguesia nacional na periferia do capitalismo, ou seja, uma burguesia identificada com os interesses nacionais. Por conseguinte, a burguesia não conseguiria liderar uma revolução nacional e capitalista.

Apesar disso, de acordo com Florestan Fernandes ${ }^{18}$, a burguesia não é mera "burguesia compradora", na verdade, uma característica singular das economias periféricas é a hipertrofia do poder político da burguesia, facilitando o controle burocrático do Estado. Isso porque, após a Segunda Guerra Mundial, quanto mais se aprofunda a transformação capitalista, mais as nações capitalistas centrais e hegemônicas necessitam de "apoio" para prevalecer perante os regimes socialistas. Assim, a burguesia espelhava-se no desenvolvimento de países centrais, sem, contudo, a mesma estrutura social criada durante o processo das revoluções burguesas clássicas, o que aprofundou o processo de dependência externa em relação às economias centrais.

Ainda segundo o autor ${ }^{19}$, sobre a apropriação do excedente econômico nas economias capitalistas dependentes existe uma pressão dual, aquela exercida pela burguesia nacional e aquela exercida pelas burguesias das nações capitalistas hegemônicas. Tal característica molda o projeto de “desenvolvimento” proposto pelas próprias classes políticas nas economias periféricas,

\footnotetext{
15 BRESSER-PEREIRA, Luiz Carlos. A construção política do Brasil: sociedade, economia e Estado desde a Independência. 3 ed. São Paulo: Editora 34, 2016, p. 193-194.

${ }^{16}$ Em comum, o termo dependência faz oposição ao capitalismo imperialista praticado pelas economias centrais. Sobre o tema, veja a obra Desenvolvimento Dependente (1979) de Peter Evans que ficou internacionalmente conhecida e a obra Revolução Burguesa no Brasil (1976) de Florestan Fernandes que também retratou com singularidade o fenômeno.

17 BRESSER-PEREIRA, Luiz Carlos. A construção política do Brasil: sociedade, economia e Estado desde a Independência. 3 ed. São Paulo: Editora 34, 2016, p. 203.

${ }^{18}$ FERNANDES, Florestan. A revolução burguesa no Brasil. 2 ed. Rio de Janeiro: Zahar, 1976, p. 296.

${ }^{19}$ FERNANDES, Florestan. A revolução burguesa no Brasil. 2 ed. Rio de Janeiro: Zahar, 1976, p. $292-295$.
} 
ISSN 1981-3694

(DOI): $10.5902 / 1981369437818$

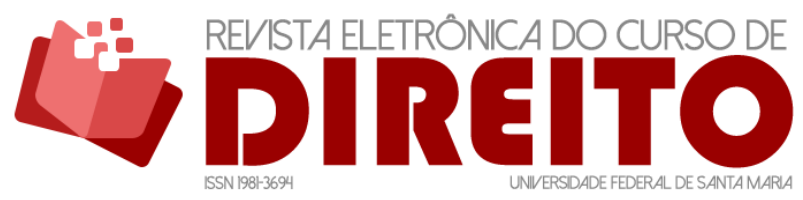

A INOVAÇÃO NO BRASIL: A ANÁLISE DOCUMENTAL DO DECRETO Nº 61.056/1967

ELISA MARA COIMBA MARCOS VINÍCIO CHEIN FERES LEONARDO DA SILVA SANT'ANNA

especialmente em um contexto de dissociação pragmática entre desenvolvimento capitalista e democracia. Portanto, a Revolução Burguesa ocorrida nos países periféricos se distingue da Revolução Burguesa ocorrida nos países centrais, essencialmente neste aspecto que repercute em questões políticas, sociais e econômicas.

Desse modo, com medo de perder o poder burocrático ${ }^{20}$, a burguesia associou-se aos setores militares e apoiou o golpe institucional de 1964. Nessa experiência, os interesses burgueses foram horizontalizados, eliminando dissensões, principalmente entre os setores mais radicais. Por conseguinte, foram sufocados tanto o reformismo burguês (exemplificado pelos dilemas decorrentes da reforma agrária quanto da expansão do mercado interno) quanto o movimento democrático-burguês (exemplificado pelo amortecimento da radicalização da classe média), a partir da própria dominação burguesa e a solidariedade sobre a qual a classe repousa. Em outras palavras, o projeto da burguesia conservadora saiu fortalecido naquele momento histórico. Florestan Fernandes ${ }^{21}$ destaca que a unidade dentro da classe burguesa assume um caráter altamente conservador e imperialista, havendo, pois, uma tendência a se alinharem os valores burgueses nacionais aos estrangeiros, incapaz de desenvolver mecanismos autoprotetivos de interesses nacionais autóctones.

Apesar disso, a burguesia não estava presente no governo Castello Branco, apenas criara condições para o golpe, especialmente porque foram os economistas e os engenheiros, conhecidos como "tecnocratas", que ocuparam os principais cargos-chave econômicos no Brasil, com exceção da presidência do Banco do Brasil. Segundo Bresser-Pereira ${ }^{22}$, o que caracteriza a tecnoburocracia é a disponibilidade ideológica, “dado que o conhecimento técnico - fator estratégico de produção em substituição à terra e ao capital - é o que dá legitimidade ao poder tecnocrático, essa legitimidade somente se confirma se a administração eficiente da economia produzir o desenvolvimento".

Quando Costa e Silva assumiu o poder, o governo tornou-se mais autoritário, especialmente com a promulgação do Ato Institucional $n^{\circ}$ 5/1968, e a esquerda mais radicalizada passou a recorrer cada vez mais à luta armada, por conseguinte, a repressão também passou a ser cada vez mais violenta. Com o tempo, a burguesia imperialista gradativamente foi sendo incorporada ao

\footnotetext{
20 Até 1964, havia uma forte organização da sociedade civil, capaz de pressionar o governo por reformas cada vez mais profundas, a exemplo do movimento operário, do partido comunista, do movimento estudantil, entre outros.

${ }^{21}$ FERNANDES, Florestan. A revolução burguesa no Brasil. 2 ed. Rio de Janeiro: Zahar, 1976 , p. 305.

22 BRESSER-PEREIRA, Luiz Carlos. A construção política do Brasil: sociedade, economia e Estado desde a Independência. 3 ed. São Paulo: Editora 34, 2016, p. 197.
} 
ISSN 1981-3694

(DOI): $10.5902 / 1981369437818$

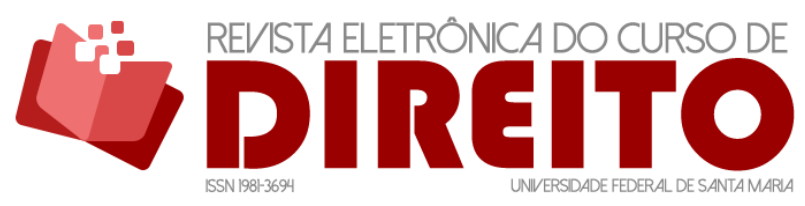

A INOVAÇÃO NO BRASIL: A ANÁLISE DOCUMENTAL DO DECRETO Nº 61.056/1967

ELISA MARA COIMBA MARCOS VINÍCIO CHEIN FERES LEONARDO DA SILVA SANT'ANNA

plano econômico em um processo desenvolvimentista com definição ideológica nacionalista, por meio de um incremento da participação dos empresários individuais que antes estavam excluídos das decisões governamentais.

Alterou-se a estratégia de um modelo econômico de substituição de importações para um modelo exportador de bens manufaturados, apesar de uma constante relação próxima com os interesses do capitalismo financeiro e das empresas multinacionais instaladas no Brasil ${ }^{23}$.

Ao descrever o início do processo econômico que deu origem ao modelo de substituição de importações, Furtado ${ }^{24}$ indica que era natural, em 1947, após a liberação das importações, que os desejos de importação manifestados pela população superassem a escala considerável para o pagamento no exterior. Para resolver isso, havia duas possibilidades: desvalorizar substancialmente a moeda ou introduzir uma série de controles seletivos de importação. A escolha pela segunda opção impactou no processo de industrialização do país, ao reduzir a concorrência externa por meio do controle das importações e ao permitir que matéria-prima e equipamentos pudessem ser garantidos a baixos preços. Furtado ${ }^{25}$ assevera que a política cambial, ao baixar os preços de equipamentos, gerou a possibilidade de o setor industrial capitalizar esse aumento de produtividade.

Após esse processo de capitalização do setor industrial, pós-Guerra Mundial, foi possível que se adotasse, no governo Costa e Silva, um modelo de ampliação do mercado consumidor, antes apenas interno, adotando o modelo exportador de bens manufaturados e gerando um superávit na balança de pagamentos, especialmente após as reformas institucionais, administrativas e fiscais adotadas pelo governo Castello Branco. Isso porque com a queda do coeficiente de importações, o modelo econômico de substituição das importações se esgotou, exigindo que a expansão dos mercados ocorra para além do mercado interno.

De acordo com o estudo empírico de Veloso et al. ${ }^{26}$, existem diversas interpretações do milagre econômico durante o governo de Costa e Silva, em alguns casos não excludentes entre si, entre as quais eles classificam em três linhas: (a) a política econômica do momento, com destaque para as políticas monetárias e creditícia; (b) a expansão da economia internacional, melhoria em

\footnotetext{
${ }^{23}$ BRESSER-PEREIRA, Luiz Carlos. A construção política do Brasil: sociedade, economia e Estado desde a Independência. 3 ed. São Paulo: Editora 34, 2016, p. 195.

${ }^{24}$ FURTADO, Celso. Formação Econômica do Brasil. São Paulo: Companhia Editora Nacional, 1971, p. 217.

${ }^{25}$ FURTADO, Celso. Formação Econômica do Brasil. São Paulo: Companhia Editora Nacional, 1971, p.222.

26 VELOSO, Fernando A.; VILLELA, André; GIAMBIAGI, Fabio. Determinantes do "milagre" econômico brasileiro (1968-1973): uma análise empírica. Revista Brasileira de Economia, v.62, n.2, 2008, pp.221-246. Disponível em: http://www.scielo.br/scielo.php?script=sci_arttext\&pid=S003471402008000200006\&lng=en\&nrm=iso. Acesso em: 09 de jan. de 2019.
} 
ISSN 1981-3694

(DOI): $10.5902 / 1981369437818$

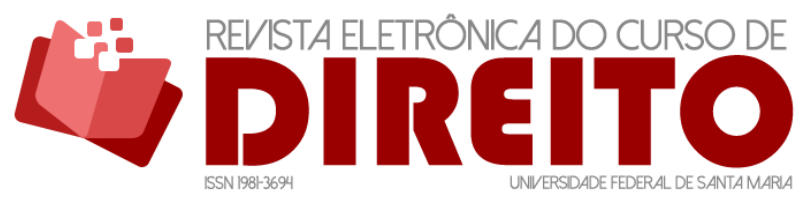

A INOVAÇÃO NO BRASIL: A ANÁLISE DOCUMENTAL DO DECRETO Nº 61.056/1967

ELISA MARA COIMBA MARCOS ViníCIO ChEIN FERES LEONARDO DA SILVA SANT'ANNA

termos de troca e crédito; (c) as reformas institucionais do Programa de Ação Econômica (PAEG) do Governo Castello Branco, em particular às reformas fiscais/tributárias e financeira. Neste estudo, os autores concluem que o crescimento associado ao milagre econômico decorreu em grande medida dos efeitos defasados das reformas do PAEG, empreendidas durante o governo Castello Branco. Além disso, sobre a desaceleração do crescimento, concluem também que três fatores tiveram importância aproximadamente igual: o efeito de convergência (à medida que as economias acumulam infraestrutura, tecnologia, o crescimento torna-se mais lento), a piora da qualidade da política econômica e os choques externos (cenário econômico internacional).

Portanto, a edição do Decreto $n^{\circ}$ 61.056/1967 e consequentemente a criação da Finep, deu-se em um momento de reforma institucional que colaborou para um posterior crescimento econômico do país.

\subsection{0 autor do Decreto $n^{\circ} 61.056 / 1967$}

O Decreto n 61.056/1967 foi assinado pelo presidente Artur da Costa e Silva e sua equipe econômica composta por Antônio Delfim Neto, Edmundo de Macedo Soares e Hélio Beltrão.

Artur da Costa e Silva nasceu no Rio Grande do Sul em 1899, filho de portugueses. Em 1912, matriculou-se no Colégio Militar de Porto Alegre. Em seguida, ingressou, em definitivo, no serviço militar, na $1^{\text {a }}$ Companhia de Estabelecimento, e, posteriormente, na Escola Militar do Realengo no Rio de Janeiro, Distrito Federal da época. Em 1922, envolveu-se no protesto contra a eleição de Artur Bernardes à Presidência, recusando-se a acompanhar o seu regimento que na repressão dos militares rebeldes integrantes da Escola Militar, o que the ensejou uma detenção no naviopresídio Alfenas. Esse movimento iniciou o ciclo de revoltas tenentistas ${ }^{27}$.

Enquanto aguardava em liberdade, mas desligado do Exército, Artur da Costa e Silva conheceu Juarez Távora. Em 1924, seu processo chegou ao fim e retornou às Forças Armadas. Devido a uma apendicite, em 1925, Artur da Costa e Silva deixou de se incorporar às forças rebeldes sob a liderança de Luís Carlos Prestes ${ }^{28}$.

Em 2 de outubro de 1930, foi deflagrado o movimento revolucionário desencadeado pela Aliança Liberal que culminou com o afastamento do presidente à época Washington Luís,

\footnotetext{
${ }^{27}$ FGV. Centro de Pesquisa e Documentação de História Contemporânea do Brasil (CPDOC). Verbete: Artur da Costa e Silva. Disponível em: http://www.fgv.br/cpdoc/acervo/dicionarios/verbete-biografico/arturda-costa-e-silva. Acesso em: 18 de nov. de 2018.

${ }^{28}$ DIMAS FILHO, Nélson. Costa e Silva; o homem e o líder. Rio de Janeiro: O Cruzeiro, 1966.
} 
ISSN 1981-3694

(DOI): $10.5902 / 1981369437818$

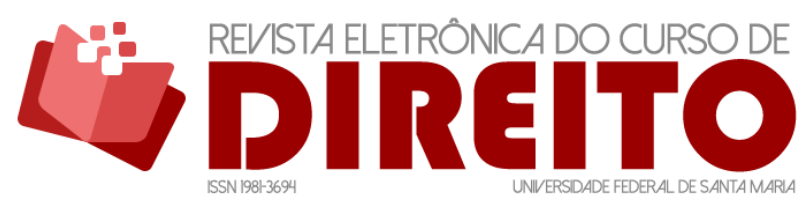

A INOVAÇÃO NO BRASIL: A ANÁLISE DOCUMENTAL DO DECRETO Nº 61.056/1967

ELISA MARA COIMBA MARCOS ViníCIO ChEIN FERES LEONARDO DA SILVA SANT'ANNA

substituído por uma Junta Militar. Nesse contexto, Artur da Costa e Silva conduziu a bandeira nacional seguindo junto com o seu regimento com vistas a ocupar o palácio da Guanabara. Em 1931, também participou da repressão da Revolução Constitucionalista de São Paulo.

Em 1938, já sob o regime do Estado Novo, serviu no gabinete do chefe do Estado Maior do Exército. No âmbito da $2^{\mathrm{a}}$ Guerra Mundial, organizou a unidade blindada que iria combater na Europa. Apoiou a posse do presidente Juscelino Kubitschek e João Goulart, desmontando um movimento de resistência por parte de um contingente da Força Aérea Brasileira (FAB). Pouco antes de ser promovido a general-de-exército, foi nomeado para comandar o IV Exército, situado em Recife, onde enfrentou um período de crise política e social em oposição ao governo de Jânio Quadros, reprimindo duramente as manifestações, tanto às estudantis quanto as de repúdio ao assassinato do presidente da Liga Camponesa de Sapé, João Pedro Teixeira ${ }^{29}$.

Em 1962, foi transferido para a chefia do Departamento Geral de Pessoal do Exército, no Rio de Janeiro, permitindo o contato com os generais Olímpio Mourão Filho, Osvaldo Cordeiro de Farias, Nélson de Melo, Odílio Denis e Humberto Castello Branco que já vinham se articulando para depor João Goulart ${ }^{30}$.

Em 1964, o general Mourão Filho levou suas tropas em direção ao Rio de Janeiro, a fim de destituir o governo, já com apoio de boa parte da oficialidade. Em seguida, foram emitidas ordens para oficiais de ligação se unirem ao movimento. Em sendo o mais antigo, Costa e Silva assumiu o Comando do Exército. João Goulart deixou Brasília, o presidente da Câmara dos Deputados assumiu o governo interinamente, mas o poder ficou na mão do Comando Supremo da Revolução, composta de três ministros, um de cada uma das Forças Armadas, entre os quais se incluía Costa e Silva. Em seguida, foi editado Ato Institucional $n^{\circ} 1 / 1964$ que previa a eleição indireta do presidente, momento em que o Congresso elegeu o presidente Castello Branco e o deputado José Maria Alkin ${ }^{31}$. O general Costa e Silva foi o segundo militar a assumir a Presidência da República.

\footnotetext{
${ }^{29}$ FGV. Centro de Pesquisa e Documentação de História Contemporânea do Brasil (CPDOC). Verbete: Artur da Costa e Silva. Disponível em: http://www.fgv.br/cpdoc/acervo/dicionarios/verbete-biografico/arturda-costa-e-silva. Acesso em: 18 de nov. de 2018.

${ }^{30}$ FGV. Centro de Pesquisa e Documentação de História Contemporânea do Brasil (CPDOC). Verbete: Artur da Costa e Silva. Disponível em: http://www.fgv.br/cpdoc/acervo/dicionarios/verbete-biografico/arturda-costa-e-silva. Acesso em: 18 de nov. de 2018.

${ }^{31}$ FGV. Centro de Pesquisa e Documentação de História Contemporânea do Brasil (CPDOC). Verbete: Artur da Costa e Silva. Disponível em: http://www.fgv.br/cpdoc/acervo/dicionarios/verbete-biografico/arturda-costa-e-silva. Acesso em: 18 de nov. de 2018.
} 


\subsection{As características e natureza do Decreto nº 61.056/1967}

Nesta subseção, reúnem-se elementos tanto associados às características de autenticidade e confiabilidade quanto associados à natureza do Decreto $n^{\circ} 61.056 / 1967$, porque, de um lado, em se tratando de um documento oficial, publicado no sítio oficial da Presidência da República, não há espaço para se discutir eventual problemática a respeito da autenticidade e confiabilidade do documento ante à inexistência de quaisquer indícios no sentido de considerá-lo não autêntico ou não confiável. Dessa forma, para efeitos deste trabalho, o Decreto $n^{\circ}$ 61.056/1967 pode ser considerado como um documento autêntico e confiável.

Por outro lado, em relação às características do Decreto n 61.056/1967, verifica-se que se trata de um ato normativo que constitui uma empresa pública, na forma estabelecida no Decreto-lei n 200/1967, ainda vigente, que realizou uma reforma administrativa na administração federal, instituindo uma nova forma de classificação: a administração direta e a administração indireta ${ }^{32}$.

Trata-se, pois, de uma reforma administrativa à época que determinou a respeito das atividades da administração pública pelos princípios do planejamento (voltado à promoção do desenvolvimento econômico e social do país), coordenação (em todos os níveis da administração), descentralização (distinguindo o nível da direção do de execução), delegação de competência (a fim de assegurar maior rapidez e objetividade quanto às decisões) e controle (exercido particularmente pela chefia competente pela execução dos programas) ${ }^{33}$.

Ainda de acordo com Alberto Venâncio Filho, neste período, o processo de intervenção do Estado na economia apareceu como uma reação pendular em relação ao ocorrido a partir de 1946, procurando restringir, nos termos da Constituição de 1967, a extensão da intervenção do Estado no domínio econômico posta na Constituição de $1946^{34}$. Optou-se, assim, por uma atuação do Estado na economia mais sistematizada em consonância com o estabelecido pelo Decreto-lei $n^{\circ}$

\footnotetext{
32 Art. $4^{\circ}$ A Administração Federal compreende: I - A Administração Direta, que se constitui dos serviços integrados na estrutura administrativa da Presidência da República e dos Ministérios. II - A Administração Indireta, que compreende as seguintes categorias de entidades, dotadas de personalidade jurídica própria: a) Autarquias; b) Emprêsas Públicas; c) Sociedades de Economia Mista; d) fundações públicas. (BRASIL. Decreto-lei n²00, de 25 de fevereiro de 1967. In: Diário Oficial da República Federativa do Brasil, Brasília, DF, 25 fev. 1967. Dispõe sôbre a organização da Administração Federal, estabelece diretrizes para a Reforma Administrativa e dá outras providências. Disponível em: <http://www.planalto.gov.br/ccivil_03/Decretolei/Del0200.htm>. Acesso em: 04 de jan. 2019)

${ }^{33}$ VENÂNCIO FILHO, Alberto. A intervenção do Estado no domínio econômico: O Direito Público Econômico no Brasil. Rio de Janeiro: Renovar, 1998, p. 587-588.

${ }^{34}$ VENÂNCIO FILHO, Alberto. A intervenção do Estado no domínio econômico: O Direito Público Econômico no Brasil. Rio de Janeiro: Renovar, 1998, p. 573.
} 
ISSN 1981-3694

(DOI): $10.5902 / 1981369437818$

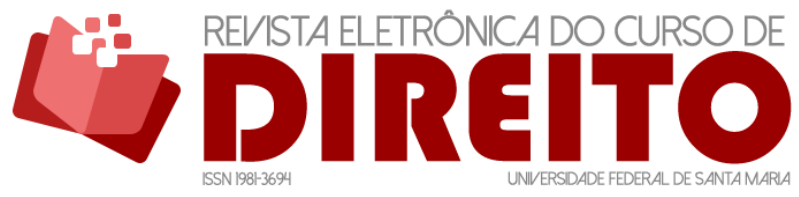

A INOVAÇÃO NO BRASIL: A ANÁLISE DOCUMENTAL DO DECRETO Nº 61.056/1967

ELISA MARA COIMBA MARCOS ViníCIO ChEIN FERES LEONARDO DA SILVA SANT'ANNA

200/1967, ao definir os conceitos de administração direta e indireta, bem como autarquia, fundações, empresas públicas, sociedades de economia mista, entre outros.

Neste contexto, a autorização para a criação da Finep, ocorreu no âmbito do próprio Decreto-lei $n^{\circ} 200 / 1967$, definindo inclusive o escopo da empresa pública a ser criada, nos termos reproduzidos abaixo:

Art. 191. Fica o Ministério do Planejamento e Coordenação Geral autorizado, se o Govêrno julgar conveniente, a incorporar as funções de financiamento de estudo e elaboração de projetos e de programas do desenvolvimento econômico, presentemente afetos ao Fundo de Financiamento de Estudos e Projetos (FINEP), criado pelo Decreto $\mathrm{n}^{\circ} 55.820$, de 8 de março de 1965, constituindo para êsse fim uma emprêsa pública, cujos estatutos serão aprovados por decreto, e que exercerá tôdas as atividades correlatadas de financiamento de projetos e programas e de prestação de assistência técnica essenciais ao planejamento econômico e social, podendo receber doações e contribuições e contrair empréstimos de fontes internas e externas ${ }^{35}$ (grifos nossos)

Assim, a finalidade pela qual o Decreto $n^{\circ} 61.056 / 1967$ foi editado diz respeito à regulamentação do artigo 191, visto que este autorizou a constituição da Finep. Dessa forma, por meio do primeiro foi criada a empresa pública denominada Financiadora de Estudos e Projetos S.A. (Finep), vinculada ao Ministério do Planejamento e Coordenação-Geral da época, a qual sucedeu o Fundo de Financiamento de Estudos e Programas (FINEP) ${ }^{36}$ em todas as obrigações ativas e passivas. Nesta linha, o corpo do Decreto n 61.056/1967 regulamentou o artigo 191, do Decretolei $n^{\circ} 200 / 1967$. Assim, por meio da autorização legislativa, consignou-se o fim social ${ }^{37}$ da empresa pública pendente de criação, bem como a demonstração do interesse social envolvido em suas atividades. Dessa forma, em seguida, a criação da empresa pública deu-se com a edição do Decreto $n^{\circ} 61.056 / 1967$, no qual se observou uma preocupação evidente em definir detalhadamente o objeto social, bem como o interesse social subjacente a sua criação, o qual será economicamente suportado pela empresa pública (vide elemento “Interesse Social”, do Quadro 2, abaixo).

Nessa linha, observa-se uma linguagem própria de instrumentos constitutivos de

\footnotetext{
${ }^{35}$ BRASIL. Decreto-lei $n^{\circ} 200$, de 25 de fevereiro de 1967. Dispõe sôbre a organização da Administração Federal, estabelece diretrizes para a Reforma Administrativa e dá outras providências. Disponível em: http://www.planalto.gov.br/ccivil_03/Decreto-lei/Del0200.htm. Acesso em: 04 de jan. 2019. (A)

${ }^{36}$ Registra-se que tal fundo tem a mesma sigla que a empresa pública constituída pelo Decreto $\mathrm{n}^{\circ}$ $61.056 / 1967$.

37 A parte geral do Código Comercial de 1850, vigente à época de edição do Decreto $n^{\circ} 61.056 / 1967$, estabelecia inclusive no artigo 295 que um dos requisitos para a dissolução de companhias de comércio ou sociedades anônimas (como a Finep) é a companhia que não pode preencher o intuito e o fim social.
} 
ISSN 1981-3694

(DOI): $10.5902 / 1981369437818$

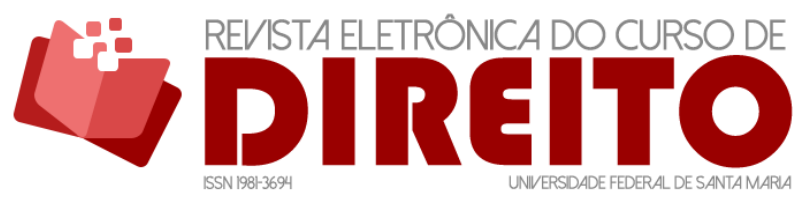

A INOVAÇÃO NO BRASIL: A ANÁLISE DOCUMENTAL DO DECRETO Nº 61.056/1967

ELISA MARA COIMBA MARCOS VINÍCIO CHEIN FERES LEONARDO DA SILVA SANT'ANNA

sociedades, sejam públicas sejam privadas, por meio da qual se pretende forjar uma identidade positiva para a pessoa jurídica recém-criada, ligada ao desenvolvimento econômico do país, tal como consta no Decreto $n^{\circ}$ 61.056/1967 e no seu Anexo (Estatuto da Finep), a exemplo do artigo $4^{\circ}, \S 2^{\circ}$, deste último (Quadro 2).

\subsection{A lógica interna do Decreto $n^{\circ} 61.056 / 1967$}

Ao longo do Decreto $\mathrm{n}^{\circ}$ 61.056/1967 fica evidente o seu objetivo organizacional e regulamentar, definindo os meios pelos quais será possível realizar o objeto social, por meio de uma organização administrativa, recursos financeiros, recursos humanos, entre outros. Por isso, ao longo do Decreto e do seu Anexo (o próprio estatuto da Finep) existem capítulos destinados ao desenho dos órgãos e atribuições vinculados, dos recursos passíveis de realização, das operações em si, do pessoal, entre outros. Abaixo, seguem os principais aspectos regulamentados pelo Decreto n 61.056/1967 (Quadro 1), bem como o seu Anexo (Quadro 2).

Quadro $1^{38}$ - Elementos do Decreto n 61.056/196739

\begin{tabular}{|c|c|c|}
\hline Elementos & Literalidade & Artigo \\
\hline $\begin{array}{l}\text { Ato de } \\
\text { constituição } \\
\text { da empresa } \\
\text { pública }\end{array}$ & $\begin{array}{l}\text { Fica constituída a Emprêsa Pública denominada Financiadora de Estudos de } \\
\text { Projetos S.A. - FINEP, vinculada ao Ministério do Planejamento e } \\
\text { Coordenação-Geral, segundo o disposto no art. } 191 \text { do Decreto-lei } n^{\circ} 200 \text {, de } \\
25 \text { de fevereiro de } 1967 \text {, e no Decreto-lei de } n^{\circ} 298 \text {, de } 28 \text { de fevereiro de } \\
1967 \text {. }\end{array}$ & Art. $1^{\circ}$ \\
\hline Objeto Social & $\begin{array}{l}\text { - A FINEP tem por objeto o financiamento da elaboração de estudos de } \\
\text { projetos e programas de desenvolvimento econômico, aplicando } \\
\text { prioritariamente os recursos de que disponha nos estudos que visem a } \\
\text { implementação das notas setoriais estabelecidas no plano de ação do } \\
\text { Govêrno, elaborado sob a responsabilidade do Ministério do Planejamento e } \\
\text { Coordenação-Geral. } \\
\text { - A FINEP atuará também no sentido de contribuir para o aperfeiçoamento } \\
\text { da tecnologia nacional, principalmente no que concerne à engenharia de } \\
\text { projetos e assistência técnica }\end{array}$ & $\begin{array}{l}\text { Art. } \\
2^{\circ}, \\
\text { caput; } \\
\text { Art. } \\
2^{\circ} \\
\text { p.u. }\end{array}$ \\
\hline $\begin{array}{l}\text { Instrumentos } \\
\text { de atuação }\end{array}$ & $\begin{array}{l}\text { - regionalização: A FINEP poderá manter representações estaduais ou } \\
\text { regionais, quando o volume de suas atribuições o justificar. } \\
\text { - Celebração de parcerias internas: Sempre que possível, a FINEP deverá }\end{array}$ & $\begin{array}{l}\text { Art. } \\
3^{\circ} \text {, } \\
\text { caput; }\end{array}$ \\
\hline
\end{tabular}

${ }^{38}$ Os quadros foram elaborados com a redação original da legislação, por isso as palavras estão com ortografia da época.

${ }^{39}$ BRASIL. Decreto $n^{\circ}$ 61.056, de 24 de julho de 1967. Regulamenta o art. 191 do Decreto-lei $n^{\circ} 200$, d e25 de fevereiro de 1967, constitui a Financiadora de Estudos de Projetos S.A (FINEP) e dá outras providências. Disponível em: http://www.planalto.gov.br/ccivil_03/decreto/19501969/D61056impressao.htm. Acesso em: 04 de nov. 2018. 
A INOVAÇÃO NO BRASIL:

\begin{tabular}{|c|c|c|}
\hline & $\begin{array}{l}\text { utilizar-se através de convênios, de outros órgãos governamentais de âmbito } \\
\text { federal, estadual ou municipal, que atuem na política de desenvolvimento, } \\
\text { como seus representantes qualificados; } \\
\text { - Celebração de parcerias internacionais: } \\
\text { i) A Emprêsa poderá celebrar convênios de empréstimos ou doações com } \\
\text { agências nacionais, estrangeiras ou internacionais, para obtenção de } \\
\text { recursos destinados às suas finalidades, podendo aceitar tôdas as cláusulas } \\
\text { e condições usuais em operações destas naturezas, sendo válido o } \\
\text { compromisso geral e antecipado de dirimir, por arbitramento, todas as } \\
\text { duvidas e controvérsias; } \\
\text { ii) O Ministério do Planejamento e Coordenação-Geral poderá negociar e } \\
\text { autorizar a contratação, junto à Agência para o Desenvolvimento } \\
\text { Internacional e ao Banco Interamericano de Desenvolvimento, de aditivos } \\
\text { aos contratos referido no art. } 4^{\circ} \text { do Decreto-lei n } 298 \text {, de } 28 \text { de fevereiro de } \\
\text { 1967, de modo a substituir o Banco Central do Brasil pela Financiadora de } \\
\text { Estudos de Projetos S.A. - FINEF na qualidade de agente da União }\end{array}$ & $\begin{array}{l}\text { Art. } \\
3^{\circ}, \\
\text { p.u.; } \\
\text { Art. } \\
6^{\circ} \text {, } \\
\text { p.u.; } \\
\text { Art. } \\
7^{\circ}, \\
\text { caput. }\end{array}$ \\
\hline $\begin{array}{l}\text { Organização } \\
\text { interna }\end{array}$ & 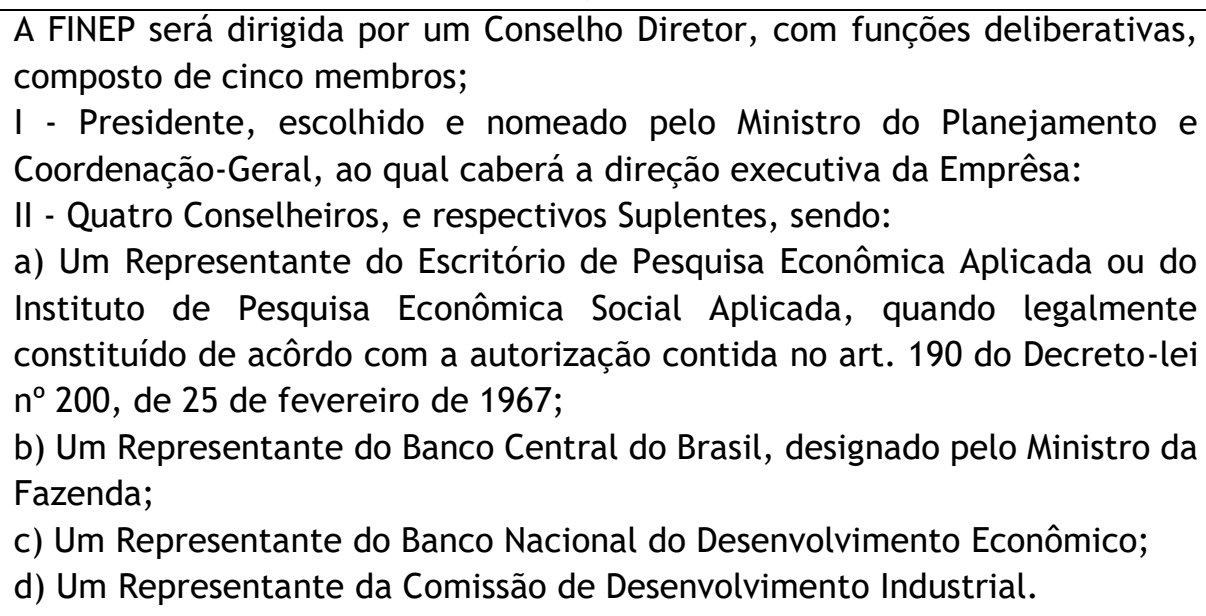 & Art. $4^{\circ}$ \\
\hline $\begin{array}{l}\text { Recursos da } \\
\text { Finep }\end{array}$ & $\begin{array}{l}\text { Constituem a receita da Emprêsa: I - Recursos provenientes de seu capital; } \\
\text { II - Dotações orçamentária da União; III - Recursos provenientes de } \\
\text { empréstimos e doações de fontes internas ou externas; IV - Produto de suas } \\
\text { operações de crédito depositado bancários e renda de bens patrimoniais; V } \\
\text { - Eventuais renda resultantes de prestações de serviços. }\end{array}$ & Art. $6^{\circ}$ \\
\hline Capital Social & $\begin{array}{l}\text { O Capital social da Emprêsa é de NCr\$1.000.000,00 (um milhão de cruzeiros } \\
\text { novos), devido em } 1.000 \text { (um mil) ações nominativas de } \mathrm{NCr} \$ 1.000,00 \text { (um } \\
\text { mil cruzeiros novos), cada uma totalmente subscritas pela União. }\end{array}$ & Art. $8^{\circ}$ \\
\hline
\end{tabular}

Fonte: Elaboração própria, a partir do Decreto $n^{\circ} 61.056 / 1967^{40}$.

${ }^{40}$ BRASIL. Decreto $n^{\circ}$ 61.056, de 24 de julho de 1967. Regulamenta o art. 191 do Decreto-lei $n^{\circ} 200$, d e25 de fevereiro de 1967, constitui a Financiadora de Estudos de Projetos S.A (FINEP) e dá outras Disponível em: http://www.planalto.gov.br/ccivil_03/decreto/19501969/D61056impressao.htm. Acesso em: 04 de nov. 2018. 


\section{Quadro 2-Elementos do Anexo do Decreto $\mathrm{n}^{\circ} 61.056 / 1967^{41}$}

\begin{tabular}{|c|c|c|}
\hline Elementos & Literalidade & Artigo \\
\hline $\begin{array}{l}\text { Tipo } \\
\text { empresarial }\end{array}$ & $\begin{array}{l}\text { - A Financiadora de Estudos de Projetos S.A - FINEP é uma emprêsa pública } \\
\text { organizada sob a forma de sociedade por ações de acôrdo com o Decreto- } \\
\text { Lei no } 298 \text {, de } 28 \text { de fevereiro de } 1967 \text {, cuja constituição foi autorizada no } \\
\text { art. } 191 \text { do Decreto-lei } n^{\circ} 200 \text {, de } 25 \text { de fevereiro de } 1967 \text {, destinada a } \\
\text { operar na área de jurisdição do Ministério do Planejamento e Coordenação- } \\
\text { Geral, e usará a sigla FINEP. } \\
\text { - A Emprêsa reger-se-á por êstes estatutos, pelos decreto que os aprova e, } \\
\text { subsidiariamente, pela legislação referente as sociedades anônimas. }\end{array}$ & $\begin{array}{l}\text { Art. } 1^{\circ} \\
\text { Art. } 2^{\circ}\end{array}$ \\
\hline Objeto Social & $\begin{array}{l}\text { A emprêsa tem por objeto o financiamento de: } \\
\text { I - elaboração de estudos de projetos ou programas de desenvolvimento } \\
\text { econômico; II - estudos de aproveitamento de recursos naturais; III - } \\
\text { serviços de assistência técnica; IV - atividades complementares, } \\
\text { relacionadas com os objetivos acima enunciados. }\end{array}$ & Art. $4^{\circ}$ \\
\hline $\begin{array}{l}\text { Interesse } \\
\text { Social }\end{array}$ & $\begin{array}{l}\text { - A FINEP aplicará prioritàriamente os recursos de que disponha nos estudos } \\
\text { que visem implementação das metas setoriais estabelecidas no plano de } \\
\text { ação do Govêrno, elaborado sob a responsabilidade do Ministério do } \\
\text { Planejamento e Coordenação-Geral. } \\
\text { - A FINEP atuará no sentido de elevar o padrão da tecnologia nacional, } \\
\text { particularmente no que concerne à programação e ao projetamento } \\
\text { econômico, ao estudo de recursos naturais e aos serviços de assistência } \\
\text { técnica. }\end{array}$ & $\begin{array}{l}\text { Art. } \\
4^{\circ}, \$ 1^{\circ} \text {; } \\
\text { Art. } \\
4^{\circ} \\
\S 2^{\circ}\end{array}$ \\
\hline $\begin{array}{l}\text { Atribuições } \\
\text { da Finep }\end{array}$ & 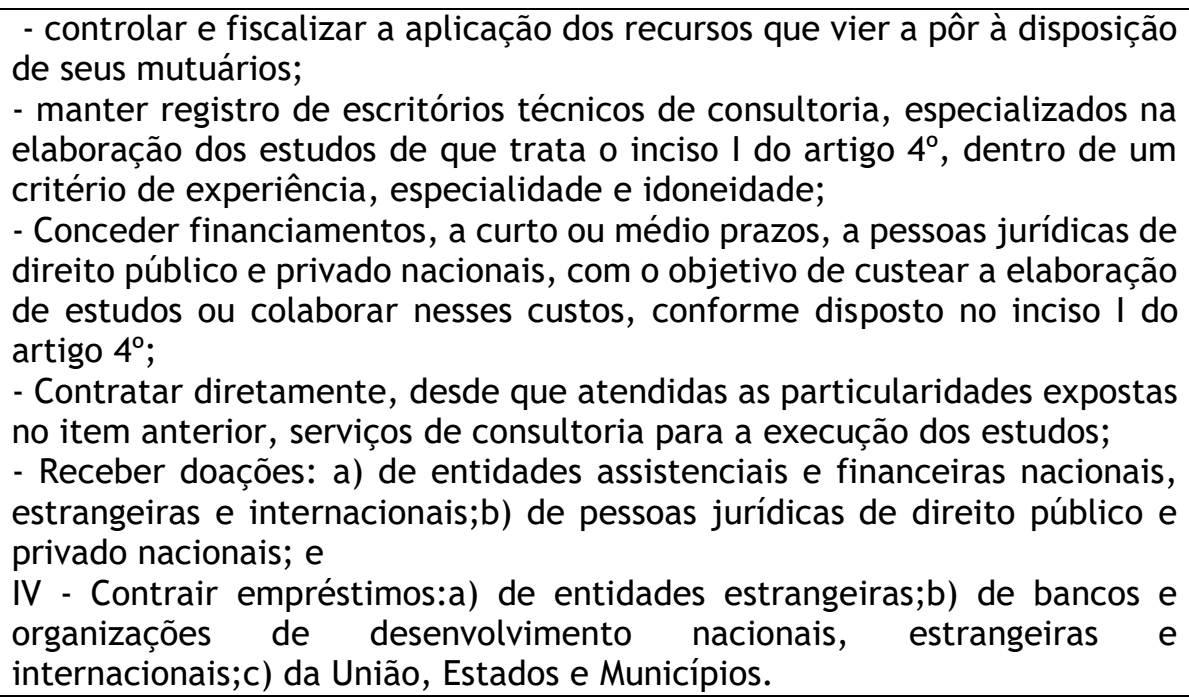 & $\begin{array}{l}\text { Art. } 5^{\circ} \\
\text { Art. } 6^{\circ}\end{array}$ \\
\hline Recursos & $\begin{array}{l}\text {-A Emprêsa disporá, para realizar suas atividades, dos recursos } \\
\text { provenientes: I - De seu capital; II - De subvenções ou dotações } \\
\text { orçamentárias da União; III - De empréstimos e doações de fontes internas }\end{array}$ & $\begin{array}{l}\text { Art. } 7^{\circ} \\
\text { Art. }\end{array}$ \\
\hline
\end{tabular}

${ }^{41}$ BRASIL. Decreto $n^{\circ}$ 61.056, de 24 de julho de 1967. Regulamenta o art. 191 do Decreto-lei $n^{\circ} 200, d$ e25 de fevereiro de 1967, constitui a Financiadora de Estudos de Projetos S.A (FINEP) e dá outras providências. Disponível em: http://www.planalto.gov.br/ccivil_03/decreto/19501969/D61056impressao.htm. Acesso em: 04 de nov. 2018. 


\begin{tabular}{|c|c|c|}
\hline & $\begin{array}{l}\text { e externas; IV - Do produto de suas operações de crédito, depósitos } \\
\text { bancários e venda de bens patrimoniais; V - De eventuais rendas resultantes } \\
\text { de prestação de serviços. } \\
\text {-Na forma do disposto nos artigos } 3^{\circ} \text { e } 4^{\circ} \text { do Decreto-lei } n^{\circ} 298 \text {, de } 28 \text { de } \\
\text { fevereiro de } 1967 \text {, dentro de } 90 \text { (noventa) dias desta data serão transferidos } \\
\text { para a Emprêsa:I - O Acervo atualmente existente no Escritório Técnico do } \\
\text { Fundo de Financiamento de Estudos de Projetos e Programas, pertencente } \\
\text { ao Gabinete do Ministro do Planejamento e Coordenação-Geral, mediante } \\
\text { tombamento; II - Os recursos provenientes de: a) doação da Agência para o } \\
\text { Desenvolvimento Internacional (USAID), de } 27.8 .65 \text {; b) empréstimo } 512-\mathrm{L} \text { - } \\
\text { 054, da USAID; c) empréstimo } 62 \mathrm{SF/BR,} \mathrm{do} \mathrm{Banco} \mathrm{Interamericano} \mathrm{de} \\
\text { Desenvolvimento. }\end{array}$ & 36 \\
\hline $\begin{array}{l}\text { Capital } \\
\text { Social }\end{array}$ & $\begin{array}{l}\text {-O capital social inicial é de NCr\$1.000.000,00 (um milhão de cruzeiros } \\
\text { novos) divididos em } 1.000 \text { (um mil) ações nominativas ordinárias, no valor } \\
\text { de NCr\$1.000,00 (um mil cruzeiros novos) cada uma. } \\
\text {-Os aumentos de capital serão feitos:I - Pela União, através de dotações } \\
\text { orçamentárias especiais; II - Por subscrição realizada pelo Banco Nacional } \\
\text { do Desenvolvimento Econômico e/ou outras entidades da administração } \\
\text { indireta; III - Pela incorporação de reservas facultativas ou fundos } \\
\text { disponíveis ou pela valorização ou avaliação de seu ativo móvel ou imóvel. }\end{array}$ & $\begin{array}{l}\text { Art. } 8^{\circ} \\
\text { Art. } \\
10\end{array}$ \\
\hline $\begin{array}{l}\text { Organização } \\
\text { Interna }\end{array}$ & $\begin{array}{l}\text { Art. 14. A Emprêsa será dirigida por um Conselho Diretor com funções } \\
\text { deliberativas, composto por cinco membros[...]. } \\
\text { Art. 15. A Emprêsa terá um Secretário-Geral, com qualificações técnicas, } \\
\text { cujas atribuições principais serão assessorar o Presidente e substituí-lo nos } \\
\text { seus impedimentos e afastamentos. } \\
\text { Parágrafo único. O Secretário-Geral será indicado pelo Presidente, e } \\
\text { nomeado pelo Ministro do Planejamento e Coordenação-Geral. } \\
\text { Art. 16. O Conselho Diretor tem funções deliberativas e reunir-se-á, } \\
\text { ordinàriamente, por quinzena, ou extraordinàriamente, quando convocado } \\
\text { por qualquer de seus membros[...]. } \\
\text { Art. 17. Compete ao Conselho Diretor:[...] } \\
\text { Art. 19. Cabe ao Presidente:[...] } \\
\text { Art. 22. O Conselho Fiscal compõe-se de três membros efetivos e de } \\
\text { suplentes em igual número, assim distribuídos:[...] } \\
\text { Art. 29. A estruturação básica dos serviços da Emprêsa será fixada em } \\
\text { Regimento Interno a ser expedido pelo Conselho Diretor, mediante prévia } \\
\text { aprovação do Ministério do Planejamento. } \\
\text { Art. } 30 \text {. Os servidores da FINEP ficam regidos pela legislação trabalhista, } \\
\text { sendo-lhes aplicáveis todos os direitos e deveres dêste estatuto jurídico e, } \\
\text { subsidiàriamente, pelo Regulamento do Pessoal, que será expedido pelo } \\
\text { Conselho Diretor, mediante prévia aprovação do Ministro do Planejamento } \\
\text { e Coordenação-Geral. }\end{array}$ & $\begin{array}{l}\text { Art. } \\
14 \text { ao } \\
\text { Art. } \\
35\end{array}$ \\
\hline
\end{tabular}

Fonte: Elaboração própria, a partir do Anexo do Decreto $\mathrm{n}^{\circ}$ 61.056/1967 42

No Quadro 1, é possível identificar as características fundamentais da estatal, as quais o Executivo considerou necessárias para cumprir as finalidades pela qual a autorização legislativa

\footnotetext{
42 BRASIL. Decreto $n^{\circ}$ 61.056, de 24 de julho de 1967. Regulamenta o art. 191 do Decreto-lei $n^{\circ} 200$, d e25 de fevereiro de 1967, constitui a Financiadora de Estudos de Projetos S.A (FINEP) e dá outras providências. Disponível em: http://www.planalto.gov.br/ccivil_03/decreto/19501969/D61056impressao.htm. Acesso em: 04 de nov. 2018.
} 
ISSN 1981-3694

(DOI): $10.5902 / 1981369437818$

A INOVAÇÃO NO BRASIL: A ANÁLISE DOCUMENTAL DO DECRETO Nº 61.056/1967

fora conferida por meio do Decreto-lei n²00/1967, qual seja: desenvolver atividades correlatadas de financiamento de projetos e programas e de prestação de assistência técnica essenciais ao planejamento econômico e social do país. No Quadro 2, por sua vez, verifica-se um incremento da densidade normativa dos elementos indicados anteriormente, especialmente considerando que neste os elementos definidos estão mais relacionados com a administração cotidiana da Finep, enquanto o Quadro 1 faz-se constar de elementos mais estratégicos à atividade negocial.

Analisando os elementos identificados acima, pretende-se explorar preferencialmente três aspectos. 0 primeiro relaciona-se ao reflexo das características da política econômica do período na organização da estatal, aproximando esta do núcleo central de decisões estratégicas do governo (o próprio Ministério do Planejamento da época), e como as ações da Finep auxiliariam o governo. Em segundo lugar, chama-se a atenção sobre como a finalidade lucrativa, elemento de empresa típico, interage com o interesse social escolhido pelo legislador em sua autorização. Por fim, o último aspecto a ser discutido nos resultados é a interação entre o capital nacional e o capital estrangeiro evidenciada tanto na composição do capital social da Finep quanto no incentivo de parcerias internacionais.

\section{Discussão dos resultados}

\subsection{Política Econômica e a Criação da Finep}

Após autorização legislativa do Decreto-lei $n^{\circ}$ 200/1967, a Finep é criada por meio do Decreto $n^{\circ}$ 61.056/1967, precedida por uma fase de ajuste econômico e de reforma administrativa, fiscal e tributária ocorridas no governo Castello Branco para a sistematização do fomento público à inovação. Desse modo, observa-se que, sem uma política econômica voltada a estimular o projeto desenvolvimentista do país, exemplificada por medidas de estímulo à importação de determinados bens em detrimento de outros ou pela neutralização da doença holandesa caracterizada pela sobreapreciação das taxas de câmbio decorrentes da exportação de commodities, produtos valorizados por alguma propriedade natural aleatória e não pelo beneficiamento industrial - o investimento poderia se transformar em consumo deixando de cumprir os objetivos inicialmente previstos. 
ISSN 1981-3694

(DOI): $10.5902 / 1981369437818$

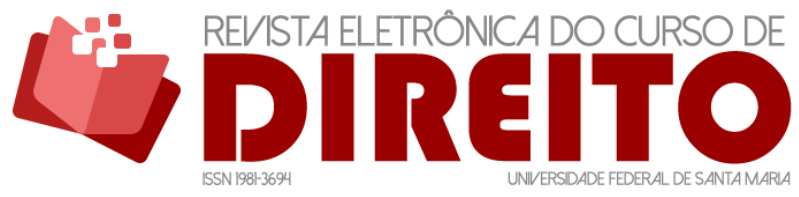

A INOVAÇÃO NO BRASIL: A ANÁLISE DOCUMENTAL DO DECRETO Nº 61.056/1967

ELISA MARA COIMBA MARCOS VINÍCIO CHEIN FERES LEONARDO DA SILVA SANT'ANNA

De acordo com Bresser-Pereira ${ }^{43}$, a industrialização brasileira, tanto na fase de substituição de importações quanto na fase exportadora de manufaturados, só foi possível pela neutralização da doença holandesa, definida como:

a sobreapreciação de longo prazo da taxa de câmbio de um país causada pelo fato que as commodities que exporta se beneficiam de rendas ricardianas e/ou são sujeitas a booms de preços, e, por isso, podem ser exportadas com lucro a uma taxa de câmbio (equilíbrio industrial) substancialmente mais apreciado do que a taxa de câmbio necessária para que as empresas de bens tradable nãocommodities que utilizam tecnologia no estado-da-arte mundial possam ser exportadas também com lucro. ${ }^{44}$

Faria sentido a criação de uma estatal que falharia em sua missão relacionada ao desenvolvimento econômico exatamente pela ausência de esforços igualmente estatais na área econômica? Por coerência, a resposta deve ser negativa, de modo que eventuais falhas estatais não decorreriam da mera ausência de planejamento. Pelo menos, na época de criação da Finep, o que não necessariamente ocorre hoje ${ }^{45}$. Nesta linha, os ajustes econômicos e as políticas econômicas desenvolvimentistas foram determinantes para a criação da Finep, bem como a escolha de suas atribuições.

De um lado, ainda que aspectos macroeconômicos não estejam explicitamente indicados no Decreto $n^{\circ}$ 61.056/1967, a preocupação com tais questões foi anterior, criando condições materiais para que as atividades atribuídas à Finep, por meio de seu objeto social ${ }^{46}$, (Quadros 1 e 2) pudessem ser executadas. O ajuste econômico anterior revelou-se como condição de possibilidade para o desempenho das atividades da Finep, o que colaborou inclusive para um momento posterior de "milagre econômico" no Brasil. Embora não seja escopo desse trabalho, ao se colocar "milagre econômico" entre aspas, tem-se em mente toda a controvérsia acerca do modelo de desenvolvimento econômico levado a cabo durante a ditadura brasileira.

Por outro lado, uma consequência da ausência de explicitação da influência das políticas econômicas no sucesso das políticas de fomento à inovação é a escolha, a posteriori, de políticas

\footnotetext{
${ }^{43}$ BRESSER-PEREIRA, Luiz Carlos. A construção política do Brasil: sociedade, economia e Estado desde a Independência. 3 ed. São Paulo: Editora 34, 2016, p. 225.

${ }^{44}$ BRESSER-PEREIRA, Luiz Carlos. A construção política do Brasil: sociedade, economia e Estado desde a Independência. 3 ed. São Paulo: Editora 34, 2016, p. 225.

45 BRASIL. Tribunal de Contas da União. ACÓRDÃO 1237/2019. Plenário. TC 017.220/2018-1. Ata n 18/2019. Data da sessão: 25/9/2019. Disponível em: https://portal.tcu.gov.br/inicio/. Acesso em: 24 set. de 2020.

${ }^{46}$ Concernente ao financiamento da elaboração de estudos de projetos e programas de desenvolvimento econômico, ao aperfeiçoamento da tecnologia nacional, a estudos de aproveitamento de recursos naturais e a serviços de assistência técnica.
} 
ISSN 1981-3694

(DOI): $10.5902 / 1981369437818$

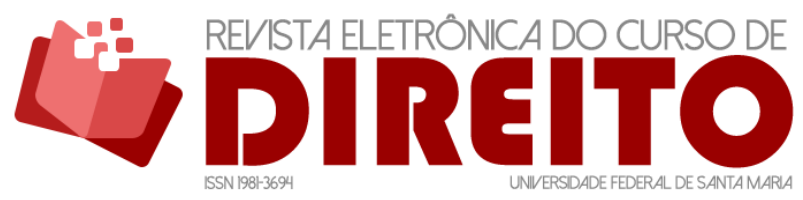

A INOVAÇÃO NO BRASIL: A ANÁLISE DOCUMENTAL DO DECRETO Nº 61.056/1967

ELISA MARA COIMBA MARCOS VINÍCIO CHEIN FERES LEONARDO DA SILVA SANT'ANNA

econômicas contraditórias às políticas de fomento à inovação ${ }^{47}$. Obviamente, tais escolhas perpassaram diversos outros governos, inclusive do período de redemocratização brasileira recente. Atualmente, a carência de uma política econômica e de inovação em sintonia favorece um contexto de descoordenação das estruturas institucionais de fomento, algumas mapeadas recentemente pelo Tribunal de Contas da União, entre elas: i) ausência de coordenação interministerial e consistência das políticas em relação ao setor produtivo, ii) ausência de alinhamento das iniciativas federais com as estaduais e municipais; iii) ausência de definição de prioridades do Estado com definição de metas e objetivos mensuráveis ${ }^{48}$.

Desse modo, não se deve negar que a execução da missão da Finep, no momento analisado, dependeu das políticas econômicas perpetradas, especialmente do ajuste econômico e da neutralização da doença holandesa da época que propiciaram um incremento do processo de industrialização com base mais tecnológica. Portanto, uma questão que se coloca para os próximos trabalhos é: até que ponto os problemas da década de 1960, em alguma medida, retornam, em especial, quando se observa um crescente processo de desindustrialização do país mascarado pelo crescimento de exportações de produtos com baixo valor agregado?

Acrescente-se ainda que apenas na recente edição do Manual de Oslo (2018) ${ }^{49}$ é que se passaram a reconhecer os aspectos macroeconômicos como fatores que influenciam a inovação nas empresas, especialmente em países em desenvolvimento. A primeira edição do Manual de Oslo, desenvolvida pela Organização para a Cooperação e Desenvolvimento Econômico (OCDE), em 1990, foi escrita com o objetivo de propor uma metodologia para coleta e interpretação de dados relacionados à inovação tecnológica. Em 2018, o Manual foi revisto pela própria OCDE em parceria com a Eurostat, aperfeiçoando as diretrizes anteriores e definindo inclusive o que se entende por inovação tecnológica, o que não ocorria na versão anterior, embora a alteração que se queira pontuar aqui, seja o reconhecimento expresso dos aspectos macroeconômicos como elementos hábeis a influenciar o processo de inovação tecnológica, especialmente em países em desenvolvimento.

Nesta linha, as atividades da Finep revelam-se interdependentes de políticas econômicas

\footnotetext{
47 BRESSER-PEREIRA, Luiz Carlos. A construção política do Brasil: sociedade, economia e Estado desde a Independência. 3 ed. São Paulo: Editora 34, 2016, p. 398.

${ }^{48}$ BRASIL. Tribunal de Contas da União. ACÓRDÃO 1237/2019. Plenário. TC 017.220/2018-1. Ata nº $18 / 2019$. Data da sessão: 25/9/2019. Disponível em: https://portal.tcu.gov.br/inicio/. Acesso em: 24 de set. de 2020. 49 OECD/Eurostat. Oslo Manual 2018: Guidelines for Collecting, Reporting and Using Data on Innovation. 4 ed. Luxemburgo: OECD Publishing, 2018. Acesso em: https://www.oecd-ilibrary.org/science-andtechnology/oslo-manual-2018_9789264304604-en;jsessionid=d7SsPJXPs44HJ6ppYzv0fT2t.ip-10-240-5-135. Disponível em: 09 de jan. de 2019.
} 
ISSN 1981-3694

(DOI): $10.5902 / 1981369437818$

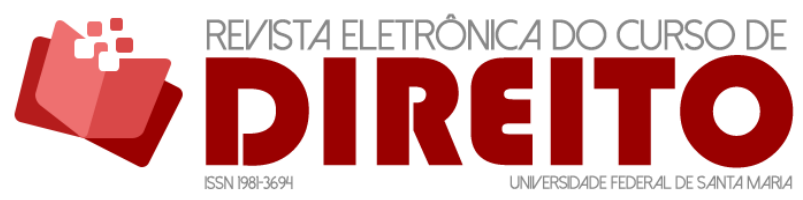

A INOVAÇÃO NO BRASIL: A ANÁLISE DOCUMENTAL DO DECRETO Nº 61.056/1967

ELISA MARA COIMBA MARCOS VINÍCIO CHEIN FERES LEONARDO DA SILVA SANT'ANNA

que igualmente the sejam favoráveis, seja no período de sua criação, seja nos dias de hoje. 0 processo de análise documental conduz a essa inferência, tendo em conta o processo de formação legislativa com foco nos elementos originários os quais se tornaram determinantes para a construção da estrutura administrativa e organizacional da Finep.

\subsection{A relação entre tipo empresarial, objeto social e interesse social}

O Decreto $n^{\circ}$ 61.056/1967 estabeleceu que a Finep seria uma empresa pública organizada na forma de uma sociedade por ações, ou seja, uma atividade com finalidade lucrativa. De acordo com a definição de empresa pública à época vinculada ao do Decreto-lei n $200 / 1967$, empresa pública é a:

a entidade dotada de personalidade jurídica de direito privado, com patrimônio próprio e capital exclusivo da União ou de suas entidades da Administração Indireta, criada por lei para desempenhar atividades de natureza empresarial que o Govêrno seja levado a exercer, por motivos de conveniência ou contingência administrativa, podendo tal entidade revestir-se de qualquer das formas admitidas em direito ${ }^{50}$.

Apesar da evidente natureza lucrativa da empresa pública, o foco do Decreto $\mathrm{n}^{\circ}$ 61.056/1967 passa muito mais por definir o interesse social, bem como atrelar o objeto social às políticas públicas desenvolvimentistas do governo. De acordo com Alberto Venâncio Filho, o surgimento da consciência do subdesenvolvimento aparece aliada ao fortalecimento do fenômeno do nacionalismo, exigindo a presença do Estado. Neste contexto, a intervenção do Estado no domínio econômico teria também o objetivo de corrigir fatores negativos decorrentes da própria condição de subdesenvolvimento dessas economias ${ }^{51}$. Essa tese ajuda a explicar a razão da ênfase de expressões relacionadas ao desenvolvimento, progresso, avanço tecnológico, entre outras, no Decreto de criação da Finep. A teoria exposta por Venâncio Filho serve de explicação para a escolha legislativa do início dos anos 70, caracterizada pela necessidade de uma intervenção do Estado dominada pelo planejamento e pela estratégia de planos governamentais os quais se

\footnotetext{
${ }^{50}$ BRASIL. Decreto-lei $n^{\circ}$ 200, de 25 de fevereiro de 1967. Dispõe sôbre a organização da Administração Federal, estabelece diretrizes para a Reforma Administrativa e dá outras providências. In: Diário Oficial da República Federativa do Brasil, Brasília, DF, 25 fev. 1967. Disponível em: http://www.planalto.gov.br/ccivil_03/Decreto-lei/Del0200.htm. Acesso em: 04 de jan. 2019.

${ }^{51}$ VENÂNCIO FILHO, Alberto. A intervenção do Estado no domínio econômico: O Direito Público Econômico no Brasil. Rio de Janeiro: Renovar, 1998, p. 14-15.
} 
ISSN 1981-3694

(DOI): $10.5902 / 1981369437818$

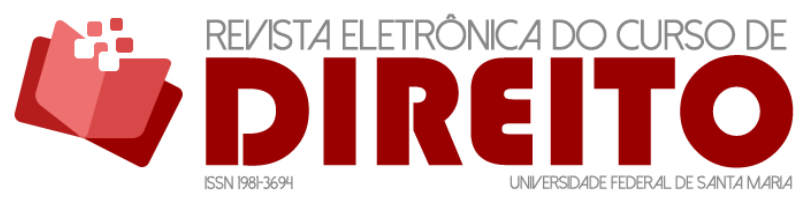

A INOVAÇÃO NO BRASIL: A ANÁLISE DOCUMENTAL DO DECRETO Nº 61.056/1967

ELISA MARA COIMBA MARCOS ViníCIO ChEIN FERES LEONARDO DA SILVA SANT'ANNA

intentam implantar durante os governos militares ${ }^{52}$, conforme já destacado com uma centralidade na atuação estratégica de um Estado marcadamente tecnocrático. Deve-se, porém, ressaltar que os planos nacionais de desenvolvimento se apresentavam como uma técnica de intervenção do estado na economia, ocupando-se o direito econômico das medidas jurídicas necessárias à execução da política econômica ${ }^{53}$. Nesse ponto, o decreto de constituição da Finep se constitui como instrumento jurídico para a possível implantação da política econômica exposta no planejamento econômico governamental.

Por conseguinte, ao inflar aspectos relacionados ao interesse social, a questão de como obter recursos para a concretização do objetivo empresarial de lucro é pouco explicitada. Em outras palavras, como obter lucro por meio de uma atuação básica focada em financiamentos diretos ou indiretos de programas, projetos ou estudos considerados prioritários, no âmbito federal, estadual ou municipal?

No caso, o Decreto $n^{0}$ 61.056/1967 valorizou mais a definição do interesse social subjacente à criação da estatal e menos à função lucrativa da Finep, especialmente quando elenca entre os recursos da empresa (Quadros 1 e 2) aqueles relacionados a doações, convênios, parcerias internas e externas, dando pouco destaque aos recursos decorrentes do retorno de seus próprios financiamentos. A explicação para esta escolha permanece um pouco obscura do ponto de vista da natureza híbrida da empresa pública, uma vez que esta se estrutura como agente econômico atuando em igualdade de condições com o particular no mercado. Todavia, deve-se ter em conta que a natureza de instrumento de intervenção do Estado na economia se sobressai ao se ressaltar o interesse social em detrimento da função lucrativa, o que parece ter sido o móvel de criação e constituição da empresa pública naquele momento histórico marcado por políticas as quais se ancoravam em uma onda nacionalista mitigada pelos interesses dos investimentos estrangeiros.

Naquele momento, pode ter-se perdido a oportunidade de incentivar a complementaridade ${ }^{54}$ entre o atendimento dos interesses sociais e a lógica de eficiência própria

\footnotetext{
52 LEOPOLDINO DA FONSECA, João Bosco. Direito Econômico. $5^{\text {a }}$ ed. Rio de Janeiro: Forense, 2005.

53 SOUZA, Washington Peluso Albino de. Primeiras linhas de direito econômico. $4^{\text {a }}$ ed. São Paulo: LTr, 1999.

${ }^{54}$ Apesar de ainda sutil, a atual Lei $n^{\circ}$ 6.404/1976, bem como a atual Lei das Estatais, detalham mais explicitamente a relação entre finalidade lucrativa própria das atividades empresariais e o interesse social envolvido na atividade econômica, a despeito da diferença sutil na literalidade dos textos legais. Isso enseja discussões doutrinárias atuais a respeito de como compensar os acionistas investidores em relação às alterações nas políticas de governo que eventualmente possam afetar a lucratividade das empresas em razão do imperativo em se atender interesses públicos que ensejaram a criação da estatal (ARAGÃO, Alexandre Santos de. Empresas estatais: o regime jurídico das empresas públicas e sociedades de economia mista. São Paulo: Gen, Editora Forense, 2017).
} 
ISSN 1981-3694

(DOI): $10.5902 / 1981369437818$

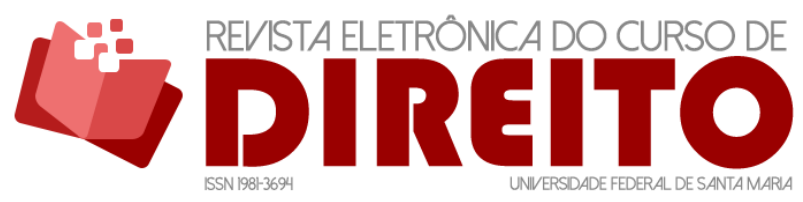

A INOVAÇÃO NO BRASIL: A ANÁLISE DOCUMENTAL DO DECRETO Nº 61.056/1967

ELISA MARA COIMBA MARCOS VINÍCIO CHEIN FERES LEONARDO DA SILVA SANT'ANNA

do mercado e das atividades econômicas em si, o que, em tese, poderia potencializar a atuação da Finep, ao realimentar seu caixa com recursos financeiros para apoiar novos projetos considerados prioritários para o país. Entretanto, não se encontraram ainda elementos empíricos suficientes que comprovem a ocorrência de efeitos decorrentes dessa possível falha estrutural.

Essa característica originária da Finep pode ter dificultado a abertura do capital social dela para investidores privados, tornando-a dependente do aporte de mais capital social, que seria posteriormente realizado pela União, conforme se identifica em alterações subsequentes do Estatuto Social.

No entanto, tal questão acaba por ser um pouco mais bem equacionada com a alteração estatutária que inclui dentro das atribuições da Finep a função de Secretaria Executiva do Fundo Nacional de Desenvolvimento Científico e Tecnológico (FNDCT), atribuindo-lhe uma taxa de administração a título de remuneração pelos serviços prestados ${ }^{55}$. Em outras palavras, o FNDCT, criado com recursos do Tesouro Nacional e administrado pela Finep na condição de Secretaria Executiva, apoia os projetos de inovação dos centros de pesquisa do país, e, em contrapartida, a Finep é remunerada com o pagamento de taxas de administração. Nesse ponto, preserva-se a natureza híbrida de mercado da empresa pública, ao mesmo tempo em que se garante a liberdade necessária às escolhas públicas de intervenção do Estado na economia.

Registra-se ainda que a personalidade jurídica de direito privado foi e permanece sendo importante na medida em que dá flexibilidade à atuação da Finep, a qual, a despeito das décadas de existência, continua atual no fomento de atividades econômicas não atrativas ao investimento privado. Um exemplo a ser citado, reconhecido, inclusive, internacionalmente, foi a atuação da Finep na criação da indústria de private equity no Brasil ${ }^{56}$, via uma iniciativa conhecida como INOVAR, quando a Finep criou um fundo para investir em empresas em estágio inicial e, ao mesmo tempo, treinou os seus "concorrentes" para atuar como investidores privados, visando ao interesse público em ter uma indústria que fomente outras empresas, as quais, no futuro, passariam a compartilhar riscos com o Poder Público ${ }^{57}$. Desprovida de personalidade jurídica de direito

\footnotetext{
${ }^{55}$ BRASIL. Decreto ${ }^{\circ} 71.133$, de 21 de setembro de 1972. Aprova o estatuto da empresa pública Financiadora de Estudos e Projetos - FINEP e dá outras providências. In: Diário Oficial da República Federativa do Brasil, Brasília, DF, 21 set. 1972. Disponível em: http://www.planalto.gov.br/ccivil_03/decreto/19701979/D71133.htm\#art5. Acesso em: 04 de nov. 2018.

${ }_{56}$ LEAMON, Ann; LERNER, Joshua. Creating a venture ecosystem in Brazil: FINEP's INOVAR Project. Harvard business school, 2011.

${ }^{57}$ Em complementação ao tema, recomenda-se a teoria a respeito do Estado Empreendedor que aprofunda o debate sobre o atual fomento à inovação: MAZZUCATO, Mariana. O Estado Empreendedor: desmascarando o mito do setor público vs. setor privado. Portfolio-Penguin, 2014.
} 
ISSN 1981-3694

(DOI): $10.5902 / 1981369437818$

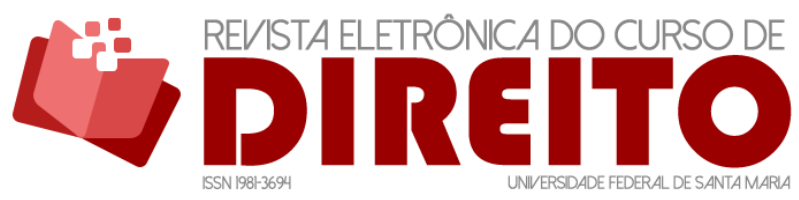

A INOVAÇÃO NO BRASIL: A ANÁLISE DOCUMENTAL DO DECRETO Nº 61.056/1967

privado, não seria possível para a Finep atuar como um agente de mercado, por exemplo.

Outro ponto que chama a atenção para a singularidade da Finep é a extensão do objeto social da empresa pública que the permite atuar desde o incentivo de projetos de pesquisa, suporte à infraestrutura laboratorial até o fomento de inovação em empresas de diferentes portes e de variados setores econômicos. Essa característica, se bem explorada, permite lidar com um dos maiores desafios da inovação em todo o mundo concernente a transformar a pesquisa em inovação, ou seja, transformar a descoberta em um produto útil possível de ser comercializada ${ }^{58}$.

\subsection{O papel do investimento estrangeiro no exercício das atribuições da Finep}

No Decreto $n^{\circ} 61.056 / 1967$, é possível identificar o papel do capital estrangeiro no processo de sistematização das políticas de inovação no âmbito da Finep.

No objeto social da Finep (Quadros 1 e 2), por meio das expressões “desenvolvimento econômico", "aperfeiçoamento da tecnologia nacional, principalmente no que concerne à engenharia de projetos e assistência técnica", verifica-se uma preponderância de projetos de engenharia e assistência técnica. Em outras palavras, por meio da intervenção do Estado no domínio econômico, a Finep, ao sinalizar para o mercado quais os projetos seriam apoiados, induziu ${ }^{59}$ os agentes econômicos a atuarem em determinado setor.

Para tal, utilizou-se do capital estrangeiro, passível de apropriação tanto por meio de parcerias internacionais quanto de doações de pessoas jurídicas externas (Quadros 1 e 2). Destacase, por ora, o parágrafo único, do artigo $6^{\circ}$ do Decreto $\mathrm{n}^{\circ} 61.055 / 1967$, relativo às receitas da empresa pública, no qual se estabelece a possibilidade de celebração de convênios de empréstimo ou doações com agências nacionais, estrangeiras ou internacionais, para a obtenção de recursos destinados às suas finalidades, podendo aceitar todas as cláusulas e condições usuais em operações destas naturezas. Registre-se, inclusive, que, entre o acervo transferido para a Finep, estão os recursos provenientes de doação e empréstimo da Agência para o Desenvolvimento Internacional (USAID) e empréstimo do Banco Interamericano de Desenvolvimento (BID) ${ }^{60}$.

Quanto aos projetos apoiados, destacam-se os dados contidos no Relatório de Atividades

\footnotetext{
58 PERKMANN, Markus et al. Academic engagement and commercialisation: A review of the literature on university-industry relations. Research policy, v. 42, n. 2, p. 423-442, 2013.

${ }^{59}$ Nomenclatura utilizada por Eros Roberto Grau no livro "A ordem econômica na Constituição de 1988 ".

${ }^{60}$ Ainda hoje os recursos provenientes do BID são significativos para diversificar as fontes, especialmente considerando a natureza não financeira do FNDCT.
} 
ISSN 1981-3694

(DOI): $10.5902 / 1981369437818$

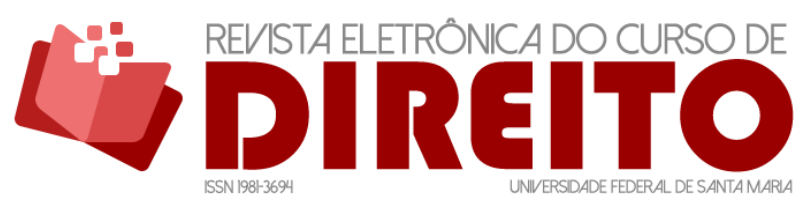

A INOVAÇÃO NO BRASIL: A ANÁLISE DOCUMENTAL DO DECRETO Nº 61.056/1967

ELISA MARA COIMBA MARCOS VINÍCIO CHEIN FERES LEONARDO DA SILVA SANT'ANNA

da Finep ${ }^{61}$ que consolidou as atividades desempenhadas por ela no período de $1965^{62}$ a junho de 1973. Segundo o documento, até 1973, a Finep (a) financiou/apoiou 355 programas, projetos e estudos, (b) implementou um cadastro de firmas de consultoria e (c) colaborou com apoio financeiro para algumas delas. Destes 355, até 1970, 92 projetos foram apoiados. 0 restante foi apoiado nos 3 anos seguintes, permitindo-se concluir que houve a expansão da Finep nos anos seguintes a sua criação. Colabora-se, com isso, a criação do FNDCT (1969) que institucionalizou a atribuição da Finep no apoio financeiro dos programas e projetos prioritários de desenvolvimento científico e tecnológico no país.

Neste primeiro relatório, que compreendeu quase a primeira década de funcionamento da Finep, é possível observar uma ampliação tanto do número de projetos apoiados quanto dos tipos de programas desenvolvidos, que inicialmente se concentraram em estudos de viabilidade e assistência técnica para posteriormente alcançar o financiamento de empresas e, por fim, o apoio da pesquisa básica por meio da criação do FNDCT ${ }^{63}$.

Em suma, a Finep, pelo menos no momento de sua criação, apoiou-se tanto na tecnocracia que compunha seus quadros quanto no capital estrangeiro para desenvolver suas atividades produtivas e consolidar a sua existência institucional, especialmente neste período inicial, momento em que o retorno dos investimentos ainda não poderia ser sentido, corroborando com um projeto de alinhamento dos valores nacionais aos estrangeiros, convergindo para a interpretação de Florestan Fernandes ${ }^{64}$ já descrita anteriormente.

\section{CONCLUSÃO}

O objetivo do trabalho foi o de compreender como ocorreu o processo de sistematização da política de inovação do Brasil, haja vista que, nos períodos anteriores, as medidas de incentivo eram instituídas à proporção que surgissem aleatórias “janelas de oportunidade”. A criação da Finep foi a própria sinalização da necessidade de se buscarem essas oportunidades de desenvolvimento, em vez de aguardá-las passivamente. Para tal, optou-se pela criação de uma

\footnotetext{
${ }^{61}$ BRASIL. FINEP. Relatório de Atividades: 1965-Junho de 1973. Rio de Janeiro, 1973, p. 13.

62 O Relatório de Atividades abarca o ano de 1965, pois considera também os projetos executados com recursos "do" FINEP (o Fundo de Financiamento de Estudos de Projetos e Programas), criado pelo Decreto $\mathrm{n}^{\circ} 55.820 / 1965$, o qual foi sucedido "pela" Finep.

${ }^{63} \mathrm{~A}$ importância a respeito da perenidade dos recursos da Finep ficou evidente recentemente tanto na discussão sobre a retirada do FNDCT da PEC dos Fundos quanto na aprovação do PLP n ${ }^{\circ} 135$ do Senado, que transforma o FNDCT em um fundo financeiro.

${ }^{64}$ FERNANDES, Florestan. A revolução burguesa no Brasil. 2 ed. Rio de Janeiro: Zahar, 1976, p. 305.
} 
ISSN 1981-3694

(DOI): $10.5902 / 1981369437818$

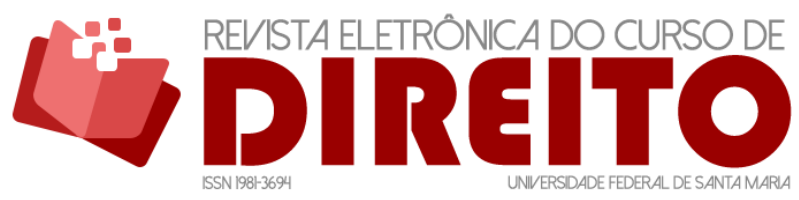

A INOVAÇÃO NO BRASIL: A ANÁLISE DOCUMENTAL DO DECRETO Nº 61.056/1967

ELISA MARA COIMBA MARCOS ViníCIO ChEIN FERES LEONARDO DA SILVA SANT'ANNA

estatal vinculada ao Ministério do Planejamento e Coordenação Geral à época, sinalizando a atuação estratégica da estatal recém-criada.

Para estudar o processo de sistematização das políticas de inovação por meio da atuação da Finep, foi necessário reconstituir o cenário econômico, político e social do momento de sua criação, de modo a identificar como tais aspectos influenciaram a organização da Finep, prevista no Decreto $n^{\circ} 61.056 / 1967$.

Neste estudo, demonstrou-se como a atuação da Finep estava alinhada ao plano de governo posto pelo regime militar, o qual foi capaz de manter coerentes as políticas de inovação e as políticas econômicas, de modo que as últimas não apenas favoreceram as primeiras, mas podem ser tidas como condições de possibilidade para as primeiras. Tal reflexão leva a concluir que o pretenso sucesso de uma política de inovação depende de uma forte articulação com o plano de governo bem como com uma política econômica favorável.

Além disso, foi possível demonstrar como os objetivos nacional desenvolvimentistas do governo foram inseridos na atuação da Finep, refletidos, em especial, no Decreto $n^{\circ}$ 61.056/1967, ainda que associados ao capital estrangeiro e a uma estrutura fortemente marcada pela tecnocracia.

Por fim, espera-se que o presente estudo ajude na compreensão das atuais políticas de fomento à inovação, explicitando interdependências entre passado e presente com potencial de auxiliar na compreensão dos desafios atuais.

\section{REFERÊNCIAS}

ALVES, Maria Helena Moreira. Estado e oposição no Brasil (1964-1984). Bauru: Edusc, 2005.

ARAGÃO, Alexandre Santos de. Empresas estatais: o regime jurídico das empresas públicas e sociedades de economia mista. São Paulo: Gen, Editora Forense, 2017.

BRASIL. Decreto-lei $n^{\circ} 200$, de 25 de fevereiro de 1967. In: Diário Oficial da República Federativa do Brasil, Brasília, DF, 25 fev. 1967. Dispõe sôbre a organização da Administração Federal, estabelece diretrizes para a Reforma Administrativa e dá outras providências. Disponível em: http://www.planalto.gov.br/ccivil_03/Decreto-lei/Del0200.htm. Acesso em: 4 jan. 2019.

BRASIL. Decreto $n^{\circ}$ 61.056, de 24 de julho de 1967. Regulamenta o art. 191 do Decreto-lei ${ }^{\circ}$ 200, d e25 de fevereiro de 1967, constitui a Financiadora de Estudos de Projetos S.A (FINEP) e dá outras providências. In: Diário Oficial da República Federativa do Brasil, Brasília, DF, 24 jul. 
1967. Disponível em: http://www.planalto.gov.br/ccivil_03/decreto/1950-

1969/D61056impressao.htm. Acesso em: 4 nov. 2018.

BRASIL. Decreto $n^{\circ} 71.133$, de 21 de setembro de 1972. In: Diário Oficial da República

Federativa do Brasil, Brasília, DF, 21 set. 1972. Aprova o estatuto da empresa pública

Financiadora de Estudos e Projetos - FINEP e dá outras providências. Disponível em:

http://www.planalto.gov.br/ccivil_03/decreto/1970-1979/D71133.htm\#art5. Acesso em: 4 nov.

2018.

BRASIL. Lei $n^{\circ} 13.303$ de 30 de junho de 2016. In: Diário Oficial da República Federativa do

Brasil, Brasília, DF, 30 jun. 2016.Dispõe sobre o estatuto jurídico da empresa pública, da sociedade de economia mista e de suas subsidiárias, no âmbito da União, dos Estados, do Distrito Federal e dos Municípios. Disponível em: http://www.planalto.gov.br/ccivil_03/_ato20152018/2016/lei/l13303.htm. Acesso em: 4 jan. 2019.

BRASIL. Lei no 6.404 de 15 de dezembro de 1976. In: Diário Oficial da República Federativa do Brasil, Brasília, DF, 15 dez. 1976.Dispõe sobre as Sociedades por Ações. In: Diário Oficial da República Federativa do Brasil, Brasília, DF. Disponível em:

http://www.planalto.gov.br/ccivil_03/LEIS/L6404consol.htm. Acesso em: 4 jan. 2019.

BRASIL. FINEP. Relatório de Atividades: 1965-Junho de 1973. Rio de Janeiro, 1973.

BRASIL. Tribunal de Contas da União. Relatório de Levantamento. Plenário. TC-002.105/2012-

8. Atan $^{\circ}$ 29/2012. Data da sessão: 1/8/2012. Disponível em: https://portal.tcu.gov.br/inicio/. Acesso em: 24 set. de 2020.

BRASIL. Tribunal de Contas da União. ACÓRDÃO 1237/2019. Plenário. TC 017.220/2018-1. Ata no 18/2019. Data da sessão: 25/9/2019. Disponível em: https://portal.tcu.gov.br/inicio/. Acesso em: 24set. de 2020.

BRESSER-PEREIRA, Luiz Carlos. A construção política do Brasil: sociedade, economia e Estado desde a Independência. 3 ed. São Paulo: Editora 34, 2016.

CELLARD, André. A análise documental. POUPART, J. et al. A pesquisa qualitativa: enfoques epistemológicos e metodológicos. Petrópolis: Vozes, 2008. p. 295-316.

DIMAS FILHO, Nélson. Costa e Silva; o homem e o líder. Rio de Janeiro : O Cruzeiro, 1966.

FERNANDES, Florestan. A revolução burguesa no Brasil. 2 ed. Rio de Janeiro: Zahar, 1976.

FGV. Centro de Pesquisa e Documentação de História Contemporânea do Brasil (CPDOC).

Verbete: Artur da Costa e Silva. Disponível em:

http://www.fgv.br/cpdoc/acervo/dicionarios/verbete-biografico/artur-da-costa-e-silva. Acesso em: 18 nov. de 2018.

FURTADO, Celso. Formação Econômica do Brasil. São Paulo: Companhia Editora Nacional, 1971. 
ISSN 1981-3694

(DOI): $10.5902 / 1981369437818$

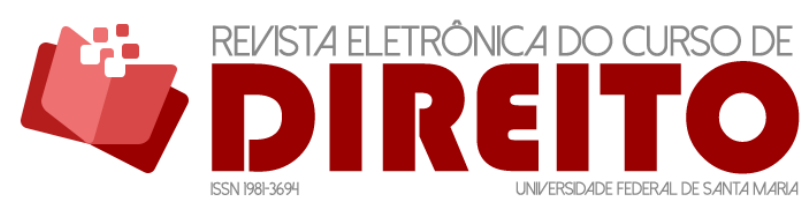

A INOVAÇÃO NO BRASIL: A ANÁLISE DOCUMENTAL DO DECRETO Nº 61.056/1967

ELISA MARA COIMBA MARCOS ViníCIO ChEIN FERES LEONARDO DA SILVA SANT'ANNA

GRAU, Eros Roberto. A ordem econômica na Constituição de 1988: interpretação e crítica. 12 ed. São Paulo: Editora Malheiros, 2007.

OECD/Eurostat. Oslo Manual 2018: Guidelines for Collecting, Reporting and Using Data on Innovation. 4 ed. Luxemburgo: OECD Publishing, 2018. Disponível em: https://www.oecdilibrary.org/science-and-technology/oslo-manual-2018_9789264304604en;jsessionid=d7SsPJXPs44HJ6ppYzv0fT2t.ip-10-240-5-135 . Acesso em: 9 jan. de 2019.

MAZZUCATO, Mariana. O Estado Empreendedor: desmascarando o mito do setor público vs. setor privado. Portfolio-Penguin, 2014.

LEAMON, Ann; LERNER, Joshua. Creating a venture ecosystem in Brazil: FINEP's INOVAR Project. Harvard business school, 2011.

PARENTONI, Leonardo Netto; VALENTINI, Rômulo Soares; ALVES, Tárik César Oliveira e. Panorama da regulação da inteligência artificial no Brasil: com ênfase no PLS N. 5.051/2019. Revista Eletrônica do Curso de Direito da UFSM, Santa Maria, RS, v. 15, n. 2, e43730, mai./ago. 2020. ISSN 1981-3694. DOI: http://dx.doi.org/10.5902/1981369443730. Disponível em: https://periodicos.ufsm.br/revistadireito/article/view/43730. Acesso em: 24 set. 2020.

PERKMANN, Markus et al. Academic engagement and commercialisation: A review of the literature on university-industry relations. Research policy, v. 42, n. 2, p. 423-442, 2013.VENÂNCIO FILHO, Alberto. A intervenção do Estado no domínio econômico: O Direito Público Econômico no Brasil. Rio de Janeiro: Renovar, 1998.

VELOSO, Fernando A.; VILLELA, André; GIAMBIAGI, Fabio. Determinantes do "milagre" econômico brasileiro (1968-1973): uma análise empírica. Revista Brasileira de Economia, v.62, n.2, 2008, pp.221-246. Disponível em: http://www.scielo.br/scielo.php?script=sci_arttext\&pid=S003471402008000200006\&lng=en\&nrm=iso. Acesso em: 9 jan. de 2019.

VETTORATO, Jardel Luís. LEI DE INOVAÇÃO TECNOLÓGICA: Os aspectos legais da inovação no Brasil. Revista Eletrônica do Curso de Direito da UFSM, v. 3, n. 3, 2008. Disponível em: https://periodicos.ufsm.br/revistadireito/article/view/7016/4235. Acesso em: 13 mar. de 2019.

Recebido em: 23.04.2019 / Revisões requeridas em: 17.09.2020 / Aprovado em: 02.10.2020 / Publicado em: 19.03.2021

\section{COMO FAZER REFERÊNCIA AO ARTIGO (ABNT):}

COIMBRA, Elisa Mara; FERES, Marco Vinício Chein; SANT'ANNA, Leonardo da Silva. A inovação no Brasil: a análise documental do Decreto No 61.056/1967. Revista Eletrônica do Curso de Direito da UFSM, Santa Maria, RS, v. 15, n. 3, e37818, set./dez. 2020. ISSN 1981-3694. DOI:

http://dx.doi.org/10.5902/1981369435597. Disponível em:

https://periodicos.ufsm.br/revistadireito/article/view/35597. Acesso em: dia mês. ano.

Direitos autorais 2020 Revista Eletrônica do Curso de Direito da UFSM

Editores responsáveis: Rafael Santos de Oliveira e Angela Araujo da Silveira Espindola (c) (i) $\odot \odot$

Esta obra está licenciada com uma Licença Creative Commons Atribuição-NãoComercial-SemDerivações 4.0 Internacional. 
ISSN 1981-3694

(DOI): $10.5902 / 1981369437818$

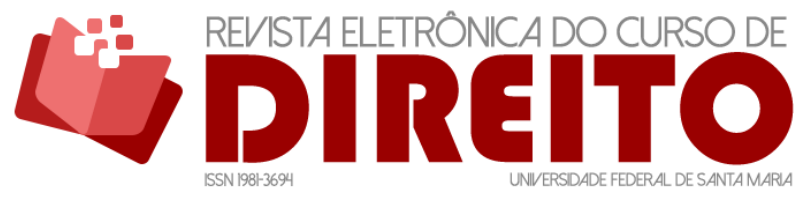

A INOVAÇÃO NO BRASIL:

\section{SOBRE OS/AS AUTORES/AS}

ELISA MARA COIMBA

Doutoranda em Empresa e Atividades Econômicas pela Universidade do Estado do Rio de Janeiro (UERJ). Mestre em Direito Constitucional e Teoria do Estado pela Pontifícia Católica do Rio de Janeiro (Puc-Rio). Graduada em Direito pela Universidade Federal de Juiz de Fora (UFJF). Advogada da Financiadora de Estudos e Projetos (Finep). Integrante do Grupo de Pesquisa Argumentação, direito e inovação da Universidade Federal de Juiz de Fora (UFJF). Integrante do Grupo de Pesquisa, Ensino e Extensão em Direito Administrativo Contemporâneo Estudos (GDAC). Colaboradora do Núcleo Jurídico OIC-IEA/USP.

\section{MARCos Vinício Chein FERES}

Atualmente é Professor Titular da Universidade Federal de Juiz de Fora, Professor do Corpo Permanente do Programa de PósGraduação Estrito Senso em Direito e Inovação da Faculdade de Direito da UFJF, Bolsista de Produtividade do CNPq e Professor Colaborador do Programa em Pós-Graduação em Direito da UERJ. Desempenhou a função de Diretor da Faculdade de Direito da UFJF (2006-2014). Desempenhou a função de Vice-Reitor da Universidade Federal de Juiz de Fora (2014-2016), assumindo o exercício da Reitoria de novembro de 2015 a abril de 2016. Possui graduação em Direito pela Universidade Federal de Juiz de Fora (1994), mestrado em Direito pela Universidade Federal de Minas Gerais (1999) e doutorado em Direito pela Universidade Federal de Minas Gerais (2003). Compõe, como participante, a Collaborative Research Network (047) da Law and Society Association, sobre "economic and social rights". Possui projetos na área de Propriedade Intelectual e Teoria do Direito Aplicada financiados pela FAPEMIG e pelo CNPq. Tem experiência na área de Direito, com ênfase em pesquisa empírica em direito aplicada ao Direito Econômico, atuando principalmente nos seguintes temas: Pesquisa Empírica em Direito, Argumentação, Direito e Inovações Tecnológicas, Direito Econômico, Direito de Propriedade Intelectual (Marcas, Patentes e Inovação e Transferência de Tecnologia) e Metodologia da Pesquisa e do Ensino Jurídico.

\section{LEONARDO DA SILVA SANT'ANNA}

Possui bacharelado em Direito pela Universidade do Estado do Rio de Janeiro (UERJ - 1997), especialização em Planejamento, Implementação e Gestão da Educação a Distância (UFF - 2015), mestrado em Direito pela Universidade Gama Filho (UGF - 2002) e doutorado em Saúde Pública pela Escola Nacional de Saúde Pública Sérgio Arouca (ENSP - 2013) da Fundação Oswaldo Cruz (FIOCRUZ). Parecerista da Seção de Propriedade Intelectual da Revista Semestral de Direito Empresarial (RSDE) , Revista Quaestio luris, da Revista da Faculdade de Direito (RFD) da UERJ e do Conselho Nacional de Pesquisa e Pós-Graduação em Direito (CONPEDI). Professor Adjunto de Direito Comercial. Professor do Programa de Pós-Graduação em Direito (PPGD) e da Graduação da Faculdade de Direito da UERJ. Foco de interesse: propriedade industrial, falência e recuperação judicial de sociedades empresárias, direito cambiário, direito do consumidor, empresa individual de responsabilidade limitada, direito sanitário, saúde e trabalho, promoção da saúde, informação e saúde, meio ambiente e saúde pública, e nanotecnologia. 